\title{
Euthecosomata (Mollusca, Gastropoda, Thecosomata). Taxonomic review
}

By Jeannine RAMPAL ${ }^{(1)}$

(1) Aix-Marseille Université, IMBE CNRS 7263 IRD 237

3 Place Victor Hugo (case 36), CS 80249

13331 Marseille Cedex 3 France30/11

E-mail : jane.rampal@gmail.com

\section{CONTENTS}

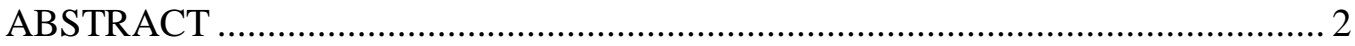

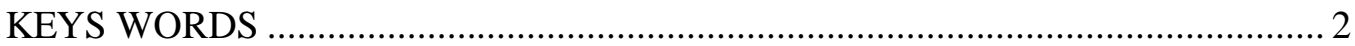

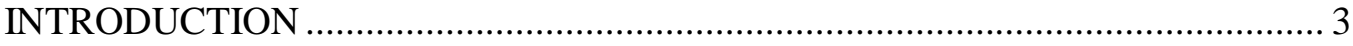

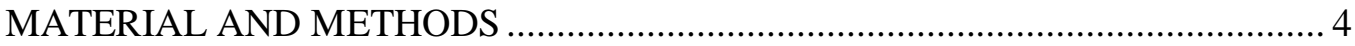

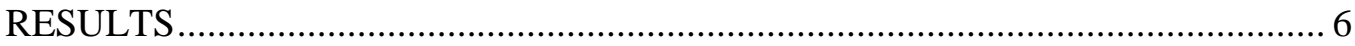

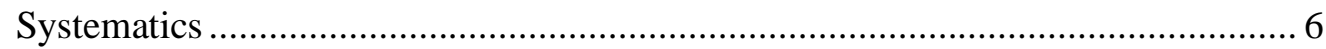

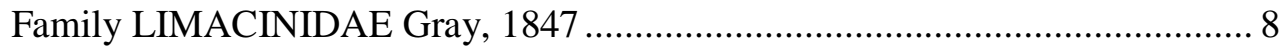

Family HELICONOIDIDAE $\mathrm{n}$. fam.......................................................... 11

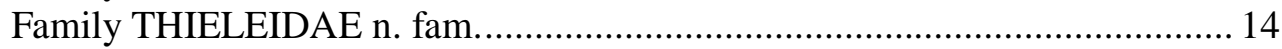

Family CRESEIDAE Rampal, 1973 .......................................................... 18

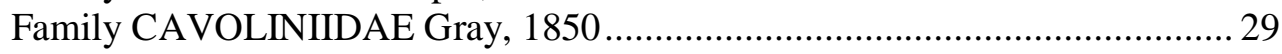

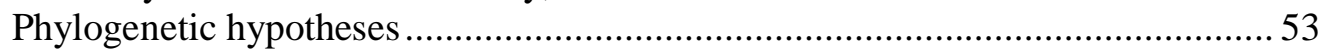

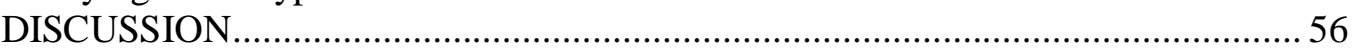

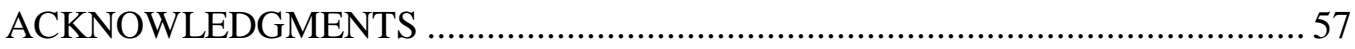

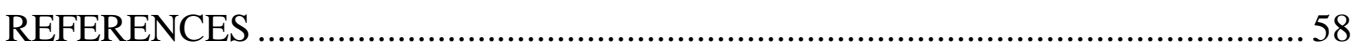

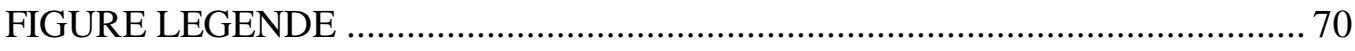




\section{ABSTRACT}

The Euthecosomata Meisenheimer, 1905, holoplanktonic Mollusca with coiled or straight shell were respectively classified in Limacinoidea Gray, 1847 and Cavolinioidea Gray, 1850. In a biometrical analysis (Rampal 1973) a first change had occurd in this last superfamily: the conica shell genera Creseis Rang, 1828, Boasia Dall, 1889, Styliola Gray, 1850 and Hyalocylis Fol, 1875 were gathered into the Creseidae Rampal, 1973. Therefore it was necessary to carry on this study using molecular data. Our recent cladistic and molecular analyses as well as palaeontologic data led to a systematic and phylogenetic revision of the Euthecosomata: the Limacinoidea and of the Creseidae are not monophyletic, the other straight shells Euthecosomata are monophyletic (Corse et al. 2013).

The Limacinoidea are invalidated; they are split into three families: Limacinidae Gray, 1847, Heliconoididae n. fam. and Thieleidae n. fam. The Creseidae Rampal, 1973 are validated but at least there are two genera Creseis Rang, 1828 and Boasia Dall, 1889; Styliola and Hyalocylis are considered incertae sedis. In the Cavoliniidae Gray, 1850 there are four subfamily: Cuvierininae Gray, 1850 , Cliinae Jeffreys, 1869 , Diacriinae n. subfam., Cavoliniinae Gray, 1850. The Creseidae Rampal, 1973 and the Cavoliniidae Gray, 1850 belong to the Cavolinioidea Gray, 1850. The species rank of most taxa is confirmed. New genera are proposed or reinstated: Telodiacria n. gen., Hyalaea de Blainville, 1821, Boasia Dall, 1889. The fossil Vaginella Daudin, 1800 is included within the Cuvierininae Gray, 1847. The spiral fossil Altaspiratella Korobkov, 1966 is no longer considered part of the Limacinidae Gray, 1847.

Two phylogenetic hypotheses are analysed. According to molecular analyses in COI there is the double emergency of straight shell from two coiled shell lineages; in $28 \mathrm{~S}$ there is monophyly; this last hypothesis we have kapt is the most parsimonious but requires some reserve and new investigations (Corse et al. 2013).

\section{KEYS WORDS}

Euthecosomata, cladistic, molecular biology, taxonomy, palaeontology, phylogeny. 


\section{INTRODUCTION}

Between the Thanetian (Latest Paleocene) (Watelet \& Lefèvre 1885) when the Euthecosomata first appeared and the Pliocene two morphotypes, coiled and straight-shaped shell, have diversified. Chronology and shape of fossils records coupled with phylogenetic analyses suggest that their adaptation to a planktonic environment included several stages. First the appearance of swimming organs in the spiral shell populations followed the acquisition and optimisation of straight shell of which successively evolved from conical to cylindrical pyramidal and globular. The spiral and the straight shell species were respectively classified into the Limacinoidea Gray, 1847 and Cavolinioidea Gray, 1850. In a biometrical study (Rampal 1973), the latter was separated into two families Cavoliniidae Gray, 1850 and Creseidae Rampal, 1973. Therefore a new analysis based on molecular data was necessary. The addition of our recent molecular analyses (Corse et al. 2013) to descriptive and evolutionary systematic data has led to a systematic revision. The Limacinoidea Gray, 1847 are broken up; the Creseidae Rampal, 1973 are redefined with the exclusion of Styliola Gray, 1850 and Hyalocylis Fol, 1875. The Cavolinioidea Gray, 1850 are restructured.

Following these recent and new insights, it was necessary to recapitulate the current knowledge about this clade: in addition to this last cladistic and molecular study, a detailed specific analysis of the phylogenetic trees for a complementary taxonomic evaluation is presented. New taxa are described and the systematic rank of several species is validated. A discussion of two phylogenetic hypotheses is tackled: single or double emergency of the straight shell Euthecosomata. Palaeontological data give valuable perspectives on these results and were compared with molecular data to estimate divergence times and also permit to follow their temporal phenotypic variations. 


\section{MATERIAL AND METHODS}

For the molecular analyses the specimens was collected during the Circum-global TARA Oceans mission (2009 - 2012) 68 stations examined. The specimens was also collected during others missions. Caribbean waters of Mexico and Belize (Eastern Coast of the Yucatan) (January 2007): $16^{\circ} 14^{\prime} \mathrm{N}-21^{\circ} 30^{\prime} \mathrm{N}$ ) / 8659 W' $-88^{\circ} 22^{\prime}$, cruise by ECOSUR (Chetunal Mexico) in collaboration with the National Oceanic Athmospheric Administration. Caribbean Sea (Virgin Islands), Missions CRER, National Oceanic Athmospheric Administration, Ship: NOAA R/V

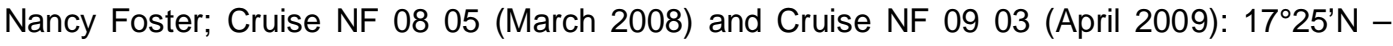
$18^{\circ} 55^{\prime} \mathrm{N} / 62^{\circ} 28^{\prime} \mathrm{W}-65^{\circ} 14^{\prime} \mathrm{W}$. Pacific Ocean, French Polynesia, Ahe Lagoon, mission FED (October 2008): $14^{\circ} 49^{\prime} \mathrm{S}-14^{\circ} 45^{\prime} \mathrm{S} / 146^{\circ} 35^{\prime} \mathrm{W}-146^{\circ} 33^{\prime} \mathrm{W}$ ). Western Mediterranean Sea, Ship: Antedon, Oceanologic Center Marseille (September 2009): $43^{\circ} 06^{\prime} \mathrm{N}-05^{\circ} 22^{\prime} \mathrm{E}$. In the text are only specifed some coordinates longitude and latitude for the positive molecular analyses specimens collected during the TARA Oceans mission.

The molecular analyses are based on two sets of data: the mitochondrial Cytochrome Oxydase I gene, COI data and data set (with and without noisy sites) and the Large Subunit of ribosomal RNA $28 S$ molecular data and gene data set (with and without noisy sites). The support values ( 0 to 1$)$ show the posterior probability in the Bayesian tree, while the values ( 0 to 100$)$ are the Maximum Likelihood bootstrap values. Supplementary molecular data from genebank and the Bar Coding of Life Database are using for singular genes (Corse et al. 2013, Tabl. 2). We also used an integrative approach to the estimation of divergence times based on the distribution of pairwise genetic distances (Corse et al. 2013). The estimate of taxa emergence periods is given in million years.

For cladistic analyses are also examined specimens collected during some oceanographic missions by N.O. : Thor, (1910); Dana (1921; 1930), Président-Théodore-Tissier (1957; 1958); Shoyo-Maru (1959); Thalassa (1961; 1963; 1969; 1977); Argonaut (1965), Jean-Charcot (1966; 1979; 1981); Ariadne (1966); Magga Dan (1966-1967); Coriolis (1967; 1969); Korotneff (1970; 1971); La Coquille (1971); Marion-Dufresne (1981; 1982; 1986); Missions Cyclone VI (1967), Caride 4 (1969) $\left(00^{\circ} 00^{\prime}-05^{\circ} 22^{\prime} \mathrm{S}, 169^{\circ} 57^{\prime}-152^{\circ} 32^{\prime} \mathrm{W}\right)$. 
The cladistic analysis is based on 54 variables: shell (19), parapodia-footlobe (7), head (3), pallial system (10), gill (1), alimentary system (7), genital system (6), nervous system (1); modality: presence/absence and orderly qualitative data. The matrix is available in Plos one. org Tab. S1, S2 (Corse et al. 2013). This study also includes a comparative morphological analysis of the radula (Microscopes Wild M5 and M10, Scanning Electron Microscope).

The main morphological characteristics are described in a key to the species (Rampal 2011).

Exhaustive synonymic lists can be found in Spoel (1967) quoted on page 64.

\section{ABBREVATIONS}

h: height, l: length, t: thickness, w: width, MA: millions years.

ICZN: INTERNATIONAL COMMISSION ON ZOOLOGICAL NOMENCLATURE. 


\section{RESULTS}

\section{Systematics}

Two orders (two clades according to Bouchet \& Rocroi 2005) Thecosomata de Blainville, 1824 and Gymnosomata de Blainville, 1824 belong to the Mollusca, Gastropoda, Euopisthobranchia (Wägele et al. 2013). They were united into Pteropoda then they were not considered monophyletic orders respectively related to Cephalaspidea and Anaspidea (Boas 1886; Pelseneer 1888; Meisenheimer 1905; Morton 1958; Spoel 1967; Salvini-Plawen 1970). Therefore the term Pteropoda was declined but often used. Unlike this point of view the monophyly was also admitted (Hoffman 1939; Odhner 1939) and now it is supported by molecular analyses: new clade including Thecosomata, Gymnosomata and Anaspidea (Dayrat et al. 2001) or Thecosomata and Gymnosomata (Jennings et al. 2010), with revival of Pteropoda (Klussmann-Kolb \& Dinapoli 2006).

\section{THECOSOMATA de Blainville, 1824}

Suborder Euthecosomata Meisenheimer, 1905: calcareous spiral or straight shell; two parapodia; proboscis absent (suborder studed in this text).

Suborder Pseudothecosomata Meisenheimer, 1905. Three cases for the shell: 1. calcareous spiral shell, 2. amino-acid straight pseudoconch (which calcareous spiral larval shell), 3. without shell; parapodial disc; proboscis.

\section{EUTHECOSOMATA Meisenheimer, 1905}

(Spiral Euthecosomata)

\section{PALAEONTOLOGICAL SUMMARY}

The earliest species known, Spirialis mercinensis (Watelet \& Lefèvre,1885) and Limacina heatherae Hodgkinson, 1992 emerged during the Upper Paleocene (Thanetian) - Lower Eocene (Ypresian) (Hodgkinson et al. 1992). After that, fossils appeared abundantly between the Lower 
and Middle Eocene and showed a high degree of diversification. Few recent species, (as well as a few rare fossils) appeared only later, at the Oligocene - Pliocene: Heliconoides inflata (d'Orbigny, 1835), Upper Oligocene (Chattian); Thielea helicoides Jeffreys, 1877, Upper Miocene (Tortonian); Limacina bulimoides (d'Orbigny, 1836), Pliocene (Hodgkinson et al. 1992; Cahuzac \& Janssen 2010).

\section{REMARKS}

The spiral shell represents the plesiomorphic state of the Euthecosomata. The caracteristic lefthanded spiral shell is allocated to the neotenic extension of larval features observed in benthic forms - unique feature on the post-metamorphic ontogenesis (Bandel et al. 1984; Bandel \& Hemleben 1995). From an anatomical perspective, the acquisition of parapodia, propelling organs derived from the foot, constitutes the first significant diversification of these planktonic Mollusca. The spiral Euthecosomata taxa were previously belonged to the Limacinoidea Gray, 1847. This superfamily was invalidated by our cladistic and molecular analyses (Corse et al. 20013).

\section{CLADISTIC AND MOLECULAR ANALYSES}

The monophyly of the Limacinoidea Gray, 1847 is supported neither by the cladistic nor by the molecular data (Corse et al. 2013).

Cladistic: no monophyly of the Limacinoidea where the genus Thielea Strebel, 1908 (characterised by a highly morphological and anatomical singularity) is the sister group to all the other Euthecosomata. The genus Limacina Bosc, 1817 is not monophyletic.

COI: Thielea helicoides (Jeffreys, 1877) + Heliconoides inflata (d'Orbigny, 1835) are the sister group to the strait shell Euthecosomata and did not form a monophyletic group with Limacina helicina (Phipps, 1774). 28S: the species of the genus Limacina Bosc, 1817 form a monophyletic lineage. However due to the absence of sequences forThielea and Heliconoides the monophyly of the Limacinoidea cannot be tested.

Nevertheless based on the congruence of cladogenesis and COI tree topologies and on the highly specialised morphological characteristics of Thielea, the Limacinoidea Gray, 1847 must be invalidated (Corse et al. 2013). We suggest a partition into three families: Limacinidae Gray, 
1847, Heliconoididae n. fam. and Thieleidae n. fam.

\section{Family LIMACINIDAE Gray, 1847 \\ Genus Limacina Bosc, 1817}

(Figs $1 ; 5 ; 6)$

Type species: Clio helicina (Phipps, 1774: 195)

DIAGNOSIS: Spiral shell, apex more or less hilly: apical angle $=55^{\circ}-125^{\circ}$, ombilic, dorsal pallial cavity, Oviparity.

Limacina helicina Bosc, 1817: 42.

Spiratella limacina de Blainville, 1824: 284 .

Heterofusus retroversus Flemming, 1823: 498

Atlanta (Heliconoides) inflata d'Orbigny, 1835:174

Spirialis rostralis Eydoux and Souleyet, 1840: 235

Scaea stenogyra Philippi, 1844:164

Heliconoides inflatus Hermannsen, 1846: 514

Protomedea elata Costa, 1861: 430

Embolus rostralis Jeffreys, $1870: 86$

Altaspiratella elongatoidea Aldrich, 1887: 83 (fossil genus)

Thielea procera Strebel, 1908: 85

Limacina (Embolus) inflata Johnson, 1934: 150

Spiratella (Limacina) inflata Rampal, 1964: 1

Limacina (Thilea) inflata Spoel, 1967: 50

Species: Limacina bulimoides (d'Orbigny, 1836), L. helicina (Phipps, 1774), L. lesueurii (d'Orbigny, 1836), L. retroversa (Flemming, 1823), L. trochiformis (d'Orbigny, 1836).

The Limacinidae are the first Euthecosomata to appear.They are present from the Upper

Paleocene (Watelet \& Lefevre 1885).They are still abundant but their specific diversity decreased during the Tertiary era. 


\section{MATERIEL EXAMINED}

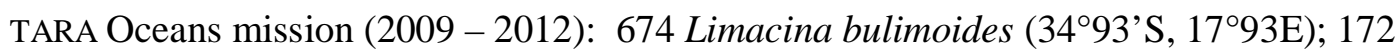

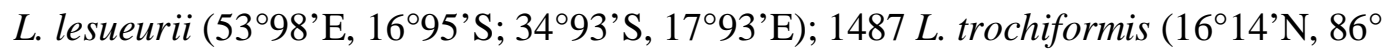

$\left.59^{\prime} \mathrm{W} ; 21^{\circ} 30^{\prime} \mathrm{N}, 88^{\circ} 22^{\prime} \mathrm{W}\right) ; 865$ L. helicina and 169 L. retroversa (Antarctic).

Western Mediterranean Sea, Caribbean Sea, South Atlantic Ocean: 88 Limacinidae.

\section{DEFINITION}

The spiral shell of Limacina has a more or less hight apex: apical angle: $55^{\circ}--125^{\circ}$. Superficial micro-ornaments are only visible with Scanning Electron Microscope (Fig. 6A). The peristome has thin edge.The calcareous microstructure of the teloconch is prismatic and /or crossedlamellar (Be et al. 1972; Rampal 1972; 1974; 1975; Richter 1976; Curry \& Rampal 1979; Glaçon et al. 1994). The microstructure of the apex is helicoidal (Fig. 6F). There is an umbilicus more or less narrow; there is no columella. Limacina has a small size: $\mathrm{w}=1-3 \mathrm{~mm}, \mathrm{~h} / \mathrm{w}=0.3-2.0$, except $L$. helicina that can reach a width of $6 \mathrm{~mm}$. The two thin parapodia are made of a single lobe each but $L$. helicina and $L$. retroversa also display a tentacular lobe on the dorsal edge of the parapodia. There is no proboscis; there is a thin cephalic lobe, and asymmetrical rhinophores. The mouth and parapodia are positioned at a similar level, like in the other Euthecosomata. The pallial cavity is dorsal. The anterior margin of the mantle is lined by a single fringe that bears some front appendages (Rampal 1975): a balancer with a basal lobe (sometimes beak-like gutter-shaped aspect) and a small expansion (Fig. 1A - C). The pallial gland includes a single layer of parallelepipedic cells on the anterior edge- second layer in the middle gland in L. trochiformis- and a multi-lobed prismatic cells area (Fig. 5A). Intestine with a single loop and multilamellar jaw. The median and lateral radular teeth are clearly distinct and highly differentiated (Vayssière 1915; Spoel 1967).

\section{CLADISTIC AND MOLECULAR ANALYSES}

The cladistic analysis gathers Limacina helicina and L. retroversa in the same group (they share the presence of a tentacular lobe on the parapodia dorsal rim similar to straight Euthecosomata, Creseis Rang, 1828. 
$28 S$ data $L$. helicina forms a paraphyletic assemblage with $L$. lesueurii, $L$. trochiformis, $L$. bulimoides. The various analyses are not congruent with respect to $L$. helicina's position. COI data set $L$. helicina is the sister group to the Pseudothecosomata. COI data it is the sister group to Hyalocylis. It is difficult to make sense of these results given the current and available data about this species.

\section{REMARKS}

The incongruence between gene trees concerning $L$. helicina does not allow this species to be positioned within the other species. In a similar fashion, our limited available data for $L$.

bulimoides, $L$. lesueurii and $L$. trochiformis, along with the confusion around $L$. helicina does not facilitate any clear conclusion regarding their belonging to the Limacinidae. These results constitute a first insight into the classification of this family.

\section{DISTRIBUTION}

In the TARA Oceans samples L. trochiformis, L. bulimoides, L. lesueurii are spread across all the oceans, found in temperate to tropical zones. In the Mediterranean Sea L. bulimoides is rare and L. trochiformis is abundant in the South Western and Eastern area; L. lesueurii is rare and restricted to the Alboran Sea: it is a marker for the presence of the Atlantic current (Rampal 1965a; 1970a; 1975). L. helicina and L. retroversa are bipolar psychrophiletic organisms. In the Arctic and Antarctic, there is a specific differentiation for L. helicina (Hunt et al. 2010). Knowledge on the diurnal bathymetric level of the Limacinidae is only partial (Rampal 1966, 1967).

\section{Genus incertae sedis}

\section{Altaspiratella Korobkov, 1966}

Altaspiratella Korobkov, 1966: 74.

Type species: Physa elongatoidea Aldrich, 1887: 83.

This fossil genus occured together with the genus Limacina: Early-Middle Eocene (Hodgkinson et al. 1992; Cahuzac \& Janssen 2010); it was classified in the Limacinidae Gray, 1847. However a striking feature that separates it from the other members of this family is the 
presence of a twisted columella ending with an abapical rostrum (Hodgkinson et al. 1992). This observation was confirmed by Cahuzac and Janssen (2010): "The columella itself is thickened and demonstrates a distinct torsion in such a way that looking into the shell's interior is possible by a straight adapical view". Moreover, contrary to Limacina, the peristome shows a notch near the columella and the umbilicus is absent. These observations are particularly significant given that Limacinidae have an umbilicus but not a columella while the Pseudothecosomata Peracle Forbes, 1844 is interestingly characterised by the presence of a columella and an absence of umbilicus as Altaspiratella. Due to lack of available data in molecular analyses for the fossil taxa, it remains difficult to definitively establish potential phylogenetical relationships between these two genera. Nevertheless, current morphological knowledge tends to support the removal of Altaspiratella from the Limacinidae. This genus is sedi.

\section{Family HELICONOIDIDAE n. fam. Genus Heliconoides d'Orbigny, 1835}

(Figs 6)

Type species: Atlanta (Heliconoides) inflata d'Orbigny, 1835

DIAGNOSIS: coiled shell, apex push in the last world of the shell: apical angle $=180^{\circ}$, ombilic, often dorsal rib, dorsal pallial cavity, prostate, pseudoviviparity.

Atlanta (Heliconoides) inflata d'Orbigny, 1835:174

Spirialis rostralis Eydoux \& Souleyet, 1840: 236

Heliconoides inflatus Hermannsen, 1846: 514

Limacina inflata Gray, 1850: 50

Limacina scaphoidea Gould, 1852: 485

Spirialis inflata Adams, 1853: 59

Heliconoides inflata Adams, 1858: 612

Protomedea elata Costa, 1861: 74

Embolus rostralis Jeffreys, 1870: 86

Protomedea rostralis Fischer, 1883: 430

Heliconoides rostralis Monterosato, 1884: 151

Spiratella inflata Hedley, 1917: 106 
Limacina (Embolus) inflata Johnson, 1934: 150

Spiratella (Limacina) inflata Vives, 1966: 126

Limacina (Thilea) inflata iSpoel, 1967: 50

Heliconoides inflata Janssen, 2003: 108

Species: Heliconoides inflata (d'Orbigny, 1835)

This species is known to be present from the Upper Oligocene onwards

MATERIAL EXAMINED

TARA Oceans mission (2009 - 2012): 3432 specimens $\left(36^{\circ} 21^{\prime} \mathrm{N}, 1^{\circ} 4^{\circ} 30^{\prime} \mathrm{E} ; 06^{\circ} 03^{\prime} \mathrm{N}, 7^{\circ} 89^{\prime} \mathrm{E}\right.$;

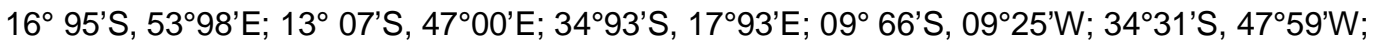

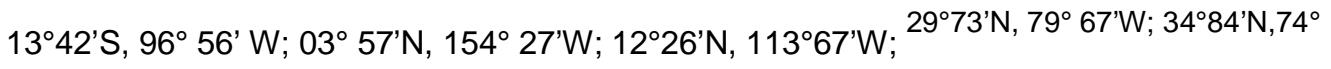
$64 ’ W)$

Western Mediterranean Sea, Caribbean Sea (Yucatan; Virgin Islands), Pacific Ocean: 92 specimens.

\section{DEFINITION}

Heliconoides inflata (d'Orbigny, 1835) differs from the other spiral Euthecosomata by a planispiral shell with an involute apex pusch into the last voluminous third whorl; $\mathrm{w}=1.2 \mathrm{~mm}$, $\mathrm{h} / \mathrm{w}=1 / 3$. It displays an oval projecting peristome with thin and sharp edge "peristome fortement saillant...bouche à bords très minces et tranchants" (d'Orbigny 1835: 175); $\mathrm{t}=3.5-6 \mu \mathrm{m}$ (Fig. $6 \mathrm{~A}-\mathrm{E})$. On the half of the third whorl there is a dorsal rib "large bande très hyaline terminée en croix près de l'orifice" (Vayssière 1915, Figs 153 - 155). Spoel (1967, Fig. 18A) makes clear that this structure consists of one or two oblique ribs on the middle of the last whorl prolonged by a narrow longitudinal rib "the rostrum" who ends near the pointed peristome. Sometimes is only present a rectilinear rib more or less tickened (Spoel 1967, Fig. 17 B), more or less short. Sometimes there is nothing rib: "coquille lisse" (d'Orbigny 1835: 175; 1836, PI.12, Figs 16 - 19). The specimens with a rectilinear rib or with two oblique and one rectilinear ribs are named type A and B (Janssen 2005). There is an opercule as the other spiral shell Euthecosomata (Rampal 
1964).

The aragonitic fibres of the ribs show a chaotic structure on the external side and a more or less prismatic structure on the internal one (Fig. 6 D). The prismatic or crossed-lamellar structure of the aperture wall is similar to the rest of the teloconch (Fig. 6 B, C) but thinner. Nevertheless this area has been compared to a glassy membrane (Rang 1828) comparable with a "columellar membrane" (Spoel 1967).

The genital system is different from the rest of all the spiral shell species: firstly there is no albumine and mucus gland, no penis, but there is a prostate where the spermatophores develop, which is directly linked to the hermaphrodite gland; secondly, embryos are attached to the internal walls of the mantle (pseudoviviparity) where they develop and the offspring is laid as veliger larvae (Lalli \& Wells 1973; Wells 1978).

MOLECULAR ANALYSES

COI: Heliconoides inflata and the Limacinidae are not monophyletic. It is the sister group to Thielea helicoides; these two species are not monophyletic with the Limacinidae; they are the sister group to the Cavolinioidea (not including Hyalocylis Fol, 1875, Cavolinia Abildgaard, 1791 and Diacavolinia Spoel, 1987). The relation between Heliconoides inflata and the other spiral species cannot be clarified. Using COI barcoding Jennings et al. (2010) shows that Heliconoides inflata is the sister group to Creseis Rang, 1828.

\section{REMARKS}

All of the present highly specific results support a separation of Heliconoides inflata from the other spiral Euthecosomata. The presence of two distinct lineages (1.00/100) in the Mediterranean and in the Caribbean Sea suggests the existence of two different molecular species geographically isolated. The highly specific morphological, anatomical, biological (pseudoviviparity) and molecular characteristics of Heliconoides prove its position into a new family. These results are corroborated by our present molecular analyses which make out four geographical species in the inflata group: Atlanto-Mediterranean, Indo-Pacific, South Eastern Atlantic and North Indian species entity; this last is only a little different to the Atlantic entity (one base) but $\mathrm{COI}$ confirm his difference (unpublished data). It is interesting to remind that 
Heliconoides is appeared from the Upper Oligocene (much later than Limacina which appears during the Upper Paleocene).

\section{DISTRIBUTION}

The species of the inflata group (many distinct geographical species) have a circumglobal distribution (except polar and boreal area). In the TARA Oceans samples this group is very frequent and abondant: $75 \%$ of positive prelevements , about $50 \%$ of the spiral Euthecosomata; maximal abondance observed in the Central Pacific Ocean.

This species have diurnal bathymetric range. Generally meso-infrapelagic, the populations have daily variations as well as seasonal migrations (linked to the laying period) during which they tend to be epipelagic (Rampal 1964; 1966; 1967; 1975: 371-379).

\section{NOMENCLATURE}

Janssen (2003) considers the fossil genus Skaptotion Curry, 1965 synonymous to the genus Heliconoides d'Orbigny, 1935:" I retain all forms with a apertural reinforcements in a single genus Heliconoides".

However, Heliconoides inflata has a thin apertural margin (see the definition above) that differs quite significantly from the apertural margin « thickened and expanded into a platform" described by Curry (1965). As a consequence according to the criterion defined by Janssen (2003), Skaptotion Curry, 1965 would not be part to the genus Heliconoides. Our molecular analyses support the position of Heliconoides into a new family Heliconoididae. Do to the lack available molecular analyses data for the fossil taxon it is impossible to check up their relation.

\section{Family THIELEIDAE n. fam. \\ Genus Thielea Strebel, 1908}

(Figs 2; 5; 7)

Type species: Limacina helicoides Jeffreys, 1877: 338.

DIAGNOSIS: calcareus spiral shell, not much apparent apex: apical angle $=125^{\circ}$, ombilic, cephalic lobe, lateral pallial cavity. Aplacental viviparity. 
Limacina helicoides Jeffreys, 1877: 338.

Thielea procera Strebel, 1908: 85

Thilea procera Tesch, 1913: 22

Spiratella helicoides Pruvot-Fol, 1954: 117

Limacina (Thilea) helicoides Spoel, 1967: 48

Thilea helicoides Rampal,1973: 1348

Thielea helicoides Janssen, 2004: 111

Species: Thielea helicoides (Jeffreys, 1877).

This species is relatively recently: Upper Miocene (Tortonian) (Janssen 2004).

MATERIAL EXAMINED

Data from Genbank and the Bar Coding of Life Database (Corse et al. 2013).

Coriolis (1967, 1969): mission Caride IV and Cyclone VI (0000', $169^{\circ} 57^{\prime} \mathrm{E} ; 01^{\circ} 14^{\prime} \mathrm{N}, 169^{\circ} 49^{\prime} \mathrm{E}$;

$\left.00^{\circ} 03 \mathrm{~N}, 152^{\circ} 32^{\prime} \mathrm{E}\right)$.

\section{DEFINITION}

Thielea can be distinguished from the other spiral species morphologically, anatomically as well as ecologically. Size: $w=10.0 \mathrm{~mm}, \mathrm{~h} / \mathrm{w}=0.9$. The genus has a thick shell, a very big last whorl. "The inner aperture margin is curved outwards, a trace of a rostrum is seen with a small columellar membrane like structure which is bigger in the Atlantic specimens than in the Pacific ones" (Spoel 1967). An umbilicus is present in most specimens (Spoel 1967). The soft parts are brown, the thick and folded parapodia look like a pseudo-parapodial disc and the posterior foot lobe is relatively small. There is a well developed cephalic lobe and a lateral pallial cavity. The anterior mantle border is membraneous, similar to a double fringe, where the internal fringe displays well developed and specialised anterior appendages: a balancer with a basal lobe and also a ventral lobe (Fig. 2A). These appendages were described by Bonnevie (1913) and Tesch (1946) as a "gill", similar (but not homologous) to a ctenidium, and as a "ventral body lobe" in a medio-ventral position. The pallial gland includes an anterior area with a few layers of prismatic multilobed cells and a large area of parallelepipedic cells elongated transversally except in the 
middle part of the gland where these cells are parallel to the antero-posterior axis (Fig. 5B). The intestine is double-looped. The median and lateral radular teeth are poorly differentiated (Vayssière 1915; Spoel 1967) and show little variety in shape and size (a notable difference from the teeth present in the other Euthecosomata); the denticles are poorly developed and irregular (Fig. 7A, A'). Another remarkable feature of Thielea helicoides is its mode of reproduction: aplacental viviparity (embryos are kept inside the mucus gland). This is unique among the spiral Euthecosomata (Wells 1978).

\section{CLADISTIC AND MOLECULAR ANALYSES}

Cladistic: Thielea is the sister group to all the Euthecosomata (first cladogenesis). COI data and data set: it is not monophyletic with the Limacinidae; it is the sister group to Heliconoides inflata; Thielea + Heliconoides are not monophyletic with the Limacinidae. Together they form the sister group to the straight Euthecosomata (not including Cavolinia Abildgaard, 1791, Diacavolinia Spoel, 1987 and Hyalocylis Fol, 1850).

\section{REMARKS}

Both cladistic and $\mathrm{COI}$ analyses show that Thielea helicoides represents a separate entity within the spiral Euthecosomata and support the removal of Thielea helicoides from the Limacinoidea Gray, 1847. On the basis of the morphological, biological (aplacental viviparity), ecological (bathypelagic) and molecular data (distinction among the other spiral species as well as its affinities with the Cavolinioidea, apart Creseis), the new family Thieleidae previously proposed (Rampal 1975) is confirmed. This genus displays some plesiomorphic characteristics similar to the hypothetical benthic ancestor; it would suggest an evolutionary reversion (Corse et al. .2013). An analysis using an integrative approach to the estimation of divergence times would be necessary to reach a better understanding of this genus evolution.

\section{DISTRIBUTION}

This bathypelagic species can be found in all the latitudes of the Atlantic Ocean, as well as some rare occurrences in the South-Western Pacific Ocean. 


\section{EUTHECOSOMATA Meisenheimer, 1905}

Superfamily CAVOLINIOIDEA Gray, 1850

(Straight Euthecosomata)

Genera: Creseis Rang, 1828, Boasia Dall, 1889, Styliola Gray, 1850, Hyalocylis Fol, 1875, Cuvierina Boas, 1886, Clio Linné, 1767, Hyalaea de Blainville, 1821, Diacria Gray, 1847, Telodiacria n. gen., Cavolinia Abildgaard, 1791 and Diacavolinia Spoel, 1987.

This superfamily represents the second significant diversification of the Euthecosomata. The transition from a spiral to a straight shell involves deep and important morphological and anatomical changes: unwinding of the visceral mass; $180^{\circ}$ twist of the trunk relative to the head: consecutively the pallial cavity is ventral (Boas 1886), latero-ventral in Clio polita and the anterior appendages are reversed. The conic shell Euthecosomata are the first to appear during the Lower Eocene.The third main diversifying event, the further optimisation into a more complex apomorphic shell occurds progressively more late.

1. All of the straight shell Euthecosomata belong to the Cavolinioidea Gray, 1850.

2. New biometrical analyses show that Creseis, Boasia, Styliola and Hyalocylis were removed from this superfamily and placed into the new family Creseidae characterised by a conical shell and some similar characteristic of the pallial complex (Rampal 1973).

3. Cladistic and molecular analyses confirm the validity of the Creseidae however limited to Creseis and Boasia (Corse et al. 2013); Styliola and Hyalocylis are considered genera of incertae sedis. Concerning the other genera of the Cavolinioidea Gray, 1850 there is incongruence: $\mathrm{COI}$ analyses do not support their monophyly but cladistic and $28 \mathrm{~S}$ molecular analyses (1.00/65) show their monophyly in the Cavoliniidae Gray, 1850 and the subdivision in four subfamilies: Cuvierininae, Cliidae, Diacriinae n. subfam. and Cavoliniinae. This family represents a new radiation: outbreak from the ancestral conical teloconch to an apomorphic teloconch characterised by a dorso-ventral depression, lateral ridge then lateral slits and then a protect lip of the peristome. The times for the different lineages divergence is corroborated by the paleontology (not exactly punctual for Clio) (Corse et al. 2013). 


\section{Family CRESEIDAE Rampal, 1973}

(Figs 1; 5)

DIAGNOSIS: straight or dorsally curved conical shell, circular transversal section, single anterior fringe on the pallial cavity, two parallelepipedic cells areas in the pallial gland.

Genera: Creseis Rang, 1828 and Boasia Dall,1889

Genus: Creseis Rang, 1828: 316

Type species: Cleodora (Creseis) virgula Rang, 1828: 316

Creseis conica Eschscholtz, 1829: 17

Criseis clava Rang \& Férussac, 1830: 261

Hyalaea aciculata d'Orbigny, 1836: 123

Cleodora acicula Deshayes \& Edwards, 1836: 433

Cresis acus Gray, 1847: 203

Styliola recta Gray, 1850: 18

Clio (Creseis) conica Pelseneer, 1888: 50

Clio conica Sykes, 1905: 329

Species: Creseis acicula (Rang, 1828), C. virgula (Rang, 1828), C. conica Eschscholtz, 1829,

Genus: Boasia Dall, 1889

Type species: Cleodora chierchiae Boas, 1886: 202

Clio (Creseis) chierchiae Pelseneer, 1888: 53

Cleodora (Boasia) Chierchiae Dall 1889: 84

Creseis chierchiae Meisenheimer, 1905: 17

Creseis (Boasia) chierchiae Johnson, 1934:151

Creseis virgula constricta Chen \& Bé, 1964: 194: 18 
Creseis chierchiae Spoel, 1967: 62

Creseis bulgia Sakthivel, 1974: 619Species: Boasia chierchiae (Boas, 1886) n. comb.

MATERIAL EXAMINED

TARA Oceans mission (2009 - 2012): 924 Creseidae. 342 Creseis acicula (1695’S, 5398’'E;

$\left.14^{\circ} 59^{\prime} \mathrm{N}, 69^{\circ} 98^{\prime} \mathrm{E}\right) ; 292$ C. conica $\left(35^{\circ} 45^{\prime} \mathrm{N}, 14^{\circ} 15^{\prime} \mathrm{E}\right) ; 154$ C. virgula $\left(73^{\circ} 89^{\prime} \mathrm{N}, 06^{\circ} 03^{\prime} \mathrm{E}\right) ; 136$

Boasia chierchiae n. comb. (14ํำ $\left.\mathrm{N}, 69^{\circ} 98^{\prime} \mathrm{E} ; 06^{\circ} 03^{\prime} \mathrm{N}, 73^{\circ} 89^{\prime} \mathrm{E}\right)$.

Western Mediterranean Sea, Caribbean Sea (Yucatan; Virgin Islands), Pacific Ocean, South

Atlantic Ocean: 26 Creseidae.

\section{PALAEONTOLOGICAL SUMMARY}

The Creseidae are the first straight Euthecosomata to appear from the Early Eocene (Ypresian)

- Middle Eocene (Chattian, Bartonian): Creseis almost concurrently to the fossils Euchilotheca

Fischer, 1883, Camptoceratops Wenz, 1923 (which shows an ongoing unwinding of the shell),

Bovicornu Meyer, 1887 and then Cheilospicata Hodgkinson, 1992 (Hodgkinson et al. 1992).

Euchilotheca shows a few features not dissimilar to some taxa: presence of an internal septum,

a platform-like peristome, an oblique peristome and parallel teloconch edges near the

peristome. Cheilospicata has a conical teloconch and a tickened platform-like peristome

reminiscent of the one seen in some fossil coiled shell species with thickened peristome.

Bovicornu has a slightly coiled teloconch-a species under dispute by some authors. All these

fossil genera was greatly expanded and diversified during the Tertiary era (Hodgkinson et al.

1992; Cahuzac \& Janssen 2010).

\section{DEFINITION}

The teloconch of this clade represents the ancestral plesiomorphic state of the Cavolinioidea. In extant species, the conical shell is thin and more or less elongated. Creseis: I $=6-20 \mathrm{~mm}$;

Boasia: $\mathrm{I}=2.0-3.5 \mathrm{~mm}$. The teloconch is straight or dorsally curved, smooth or striated for Boasia. It has a circular transversal section, and no lateral ridge. The peristome has thin edges and its transversal section is circular. The characteristic protoconch of Creseidae is only clearly seen in Boasia (pear-shaped with two constrictions) and in C. acicula (protoconch with parallel 
edges and presence of thickened internally constrictions). C. conica and C. virgula have a conical protoconch more or less flared with a randomly positioned and sized constriction. The parapodia are made of a single lobe but they have a little dorsal tentacular lobe (also present in Limacina helicina and L. retroversa). The posterior footlobe is fairly small. As the other Cavolinioidea, the Creseidae have a radula with median and lateral teeth very different and a multilobed jaw (Vayssière 1915; Spoel 1967). The pallial cavity is ventral and its margin, lined by a single fringe (Rampal 1975), bears the poorly differentiated front pallial appendages (Fig. 1E). The pallial gland is composed of two areas of parallelepipedic cells (a single-layered one on the anterior margin and a multi-layered one more posteriorly); these two areas are separated by an area of prismatic cells (Fig. 5 C).

\section{CLADISTIC AND MOLECULAR ANALYSES}

Cladistic: Creseis is the sister group to all the Cavoliniidae Gray, 1850 COI data (1.00/83), 28S (1.00/100): the Creseidae are monophyletic. COI data (1.00/ 83): they are the sister group to the Cavolinioidae Gray, 1850 (not including Hyalocylis and the Cavoliniinae Gray, $1850.28 \mathrm{~S}(0.99 / 78,1.00 / 90)$ : they are the sister group to the Cavoliniidae Gray, 1850.

COI (1.00/99, 1.00/100), 28S (0.95/93, 0.97/96): Creseis conica and C. virgula are the sister group. 28S (1.00/100): C. acicula - Boasia chierchiae n. comb. are the sister group to Creseis conica - C. virgula. COI (1.00/100,1.00/99), $28 S(0.97 / 95)$ : C. conica and C. virgula have a specific rank. COI $(1.00 / 91,0.99 / 86)$ : Boasia chierchiae $n$. comb. is the sister group to all the Creseis. 28S (1.00/96, 1.00/93): Boasia chierchiae n. comb. is the sister group to Creseis acicula. Boasia chierchiae - Creseis acicula are the sister group to C. conica -C. virgula $(1.00 / 100)$

These analyses also show distinct lineages. Boasia chierchiae n. comb.: COI (1.00/91, 0.99/ 86); $28 \mathrm{~S}$ (1.00/100, 1.00/90). Creseis acicula: COI (1.00/99, 1.00/98); 28S (1.00/93, 1.00/99). Creseis virgula - C. conica: COI (1.00/91); 28S (0.95/93, 0.96/97).

\section{REMARKS}

These analyses support the existence of the synapomorphic Creseidae. This family represents 
the plesiomorphic state of the Cavolinioidea. These analyses also consolid the species level of the four species previously reinstated with biometrical analyses and characterised by the length, width, apical angle, pluri-segmented axis curve and protoconch morphology: Creseis acicula, $C$. conica, C. virgula, Boasia chierchiae n. comb. (Rampal 1985; 2002). Afterwards these taxa were also validated at the species level by Jennings et al. (2010), by Corse et al. (2013) and by Gasca \& Janssen (2013). Each species is composed of several lineages found in different localities. This fact gives evidence to species groups for each species of Creseidae.

Genus: Creseis Rang, 1828

Creseis conica (Rang, 1828) and Creseis virgula (Rang, 1828)

No substantial regional variation was detected among Atlantic location for Creseis conica (Jennings et al. 2010). It would interesting to establish the link between the different lineages and the known phenotypes: C. conica conica Escholtz, 1829, C. c. falsiparum Rampal, 2002; C. virgula virgula (Rang, 1828), C. v. frontieri Rampal, 2002.

Creseis acicula (Rang, 1828).

This species displays a very stable needle-like phenotype on a world-scale basis; the specimens from diverse localities can be considered taxa of the cryptic species of the acicula group. These analyses show affinities between specimens from the Gulf of Aden and the South-Western Indian Ocean as well as between the ones from the Western Mediterranean and the Caribbean Sea.

Genus: Boasia Dall, 1889: 84

Type species: Cleodora chierchiae Boas, 1886: 202

DIAGNOSIS: transversaly striated teloconch; pear-shaped protoconch (two constrictions).

Species: Boasia chierchiae (Boas, 1886) n. comb.

The molecular analyses show that this species is an entity within the Creseidae. A new generic level corresponding to the hypothetical ancestor of the Creseidae is justifiable. It seems judicious to reinstate Boasia perfectly described by monotypy. Contrary to the other Creseidae, 
the teloconch of Boasia chierchiae n. comb. is more or less striated, the protoconch is pyriform with two extern constrictions and a round apex. It is the smallest Creseidae: Boasia: $\mathrm{I}=2,0-$ $3.5 \mathrm{~mm}$ (Creseis: I = 6-30 mm). His diploid chromosomes number is specific (Zarnik 1911, in Spoel 1967).

Specimens with smooth or almost smooth shell were described in the North Mozambic Channel (Frontier 1963; 1965). According to this author, the ringed form is the most neritic and the smooth or almost smooth specimens sometimes go beyond the continental rise; these two phenotypes reveal the polymorphism of a single species (Frontier 1963; 1965). In the Northern Indian Ocean and in the Red Sea, I have observed a large majority of specimens with only two or three striae. These phenotypes can be linked to Creseis bulgia (Saktivel, 1974), which is identified in the Northern Indian Ocean. Unfortunately, currently available data are not sufficient to establish the systematic level of the different Boasia chierchiae n. comb. phenotypes.

\section{DISTRIBUTION OF THE CRESEIDAE}

In the TARA Oceans samples Creseis acicula, C. conica, C. virgula and Boasia chierchiae $\mathrm{n}$. comb. respectively represent $37 \%, 31 \%, 17 \%$ and $15 \%$ of the Creseidae. The acicula group is circumglobal, frequently found in all the oceans $\left(40^{\circ} \mathrm{N}-40^{\circ} \mathrm{S}\right)$ and sometimes is very abundant. Creseis conica is the least frequent in all the area. Creseis virgula, the most thermophile, is frequent and abundant in the tropical area. Boasia chierchiae n. comb. is a typically Indo-Pacific species. However I have observed two specimens in the Caribbean Sea: are they Panama preisthmatic relics?

\section{NOMENCLATURE}

Creseis acicula (Rang, 1828)

Rang (1828) describes two narrow conical shell. Cleodora (Creseis) clava was described as transparent shell outside water level, very elongated and sometimes irregularly flexuous, sharp apex, small and round aperture and smooth surface. I $=0,022$. It is never perfectly straight (Rang 1828: 317, 318). He also describes Cleodora (Creseis) acicula (p.318) as a more transparent shell, needle-like, smaller than the previous one, always flexuous, with a very small aperture and smooth surface. $I=0,012$. He does not think that is a young specimen of the 
previous one, rather a variety.

C. clava was the valid name used by some authors (Rang and Férussac 1830; Forbes 1844;

Deshayes and Milne Edwards 1836; Cantraine 1841; Issel 1869). Souleyet (in Rang \& Souleyet

1852: 56, 57), drawing from Rang's material, concluded that it is not possible to distinguish

between the two species and proposes to choice the species Creseis acicula and the

subspecies clava.

If there is any doubt about priority, we'll adopt the one chosen by the $1^{\text {st }}$ revisor (ICZN). Thus

Creseis acicula has been used as valid by Souleyet (in Rang \& Souleyet 1852) and almost

universally adopted. Therefore the $C$. clava reinstatement due to the page priority (Janssen

2007) is not valid.

\section{TAXONOMY}

The infra-specific taxon clava was a source of confusions: Creseis acicula acicula and C. a. clava (Tesch 1913; Spoel 1967). Creseis virgula (Rang, 1828), Creseis conica Eschscholtz, 1829. Criseis clava Rang \& Férussac, 1830 set apart from acicula (Rang,1828) (Tesch 1948).

C. virgula virgula, C. v. conica, C. v. clava and C. acicula (Chen \& Bé 1964). So the belonging to a precise species seem still unsolved.

Superfamily CAVOLINIOIDEA Gray, 1850

Incertae sedis

Genus Styliola Gray, 1850

(Figs $1 ; 5 ; 7$ )

Type species: Cleodora subula Quoy \& Gaimard, 1827: 233.

DIAGNOSIS: conical shell, oblique longitudinal groove, circular transversal section, single anterior pallial fringe, two parallelepipedic cells area in the pallial gland.

Styliole recta de Blainville, 1827: 655

Cleodora subula Quoy \& Gaimard, 1827: 233

Cleodora (Creseis) spinifera Rang, 1828: 313

Hyalaea subula d'Orbigny, 1834: 77 
Styliola subula Gray, 1850: 17

Clio subulata Jeffreys, 1870: 86

Species: Styliola subula (Quoy \& Gaimard, 1827)

This species was present from the Late Oligocene

MATERIAL EXAMINED

TARA Oceans mission (2009 - 2012): 173 specimens (1695’S, 535'ㅌ).

Western Mediteranean Sea, Caribbean Sea (Yucatan; Virgin Islands): 73 specimens.

\section{DEFINITION}

Styliola subula has a conical teloconch $(I=7.0-13.0 \mathrm{~mm})$ with a circular section. An oblique and longitudinal groove extends the peristome across the anterior two thirds of the dorsal side, and forms a thin pointed overhang. The peristome itself has thin edges. The pear-shaped protoconch is comparable but not similar to one observed in Cuvierina Boas, 1886. The parapodia are proportionally short with respect to the body size. The posterior footlobe is semicircular like that of Diacria Gray, 1847 and Clio Linnaeus, 1767. The single fringe on the anterior margin of the mantle bears a long balancer and a short expansion (Fig. 1D). In the pallial gland the separation line between the two areas of parallelepipedic cells and the area of prismatic cells is ondulate (Fig. 5E). The radular teeth have a long and thin cuspide and their base is covered with fine denticles (Fig. 7C).

\section{CLADISTIC AND MOLECULAR ANALYSES}

Cladistic: Styliola is the sister group to Hyalocylis and to the Cavoliniidae. $28 \mathrm{~S}$ mol. data. (0.83/): it is the sister group to Hyalaea cuspidata (Bosc, 1802) (syn. Clio cuspidata) and they are the sister group to the Cavoliniidae. 28S gene data set: it is the sister group to Hyalaea cuspidata and they are the sister group to Cuvierina Gray, 1847 and Clio Linnaeus, 1767.

REMARKS 
These analyses all support the removal of Styliola from Creseidae Rampal, 1973. Based only on the comparison of the ancestral or derived features of their teloconch, affinities between Styliola and Cuvierina do not seem substantiated. Nevertheless, taking into account characteristics of the embryonic development sheds a new light on these affinities. Styliola could be the first rising lineage from a Cuvierina-like ancestor and displayed its actual morphology about $24 \mathrm{MY}$ ago. Indeed, the conical plesiomorphic teloconch of Styliola seems a reminiscent juvenile shell with comparable protoconch of Cuvierina. Styliola could represent a neotenic form of Cuvierina (Corse et al. 2013). The embryonic development of Styliola stopped at an early stage, corresponding to the ancestral conical stage. Nevertheless the polytomy Styliola - Cuvierina do not permit an hypothetic link; so, Styliola would be considered genus of incertae sedis. In $28 S$ gene data set (1.00/100) Styliola subula is only represented by a single species ; however these interpretations are difficult to substantiate due to the lack of results in the other analyses.

\section{DISTRIBUTION}

In the TARA Oceans samples Styliola subula represents $11 \%$ of Cavolinioidea; it is present in all the oceans $\left(40^{\circ} \mathrm{N}-40^{\circ} \mathrm{S}\right)$ and frequently found in the South-Western and Eastern Mediterranean Sea (Rampal 1975).

\section{Superfamily CAVOLINIOIDEA Gray, 1850}

Incertae sedis

Genus Hyalocylis Fol, 1875

(Figs $1 ; 5 ; 7$ )

Type species: Cleodora (Creseis) striata Rang, 1828

DIAGNOSIS: striated and dorsally curved conical shell, ellipsoidal section, deciduous juvenil shell, single anterior pallial fringe, two parallelepidedic cells area, and dumbbell-shaped layer in the prismatic area.

Cleodora (Creseis) striata Rang, 1828: 315 
Creseis compressa Eschscholtz, 1829: 17

Hyalaea striata d'Orbigny, 1836: 121

Cleodora striata Deshayes \& Edwards, 1836: 433

Criseis striata Forbes, 1844: 132

Styliola striata Gray, 1850: 18

Clio striata Jeffreys, 1870: 86

Hyalocylis striata Fol, 1875:177

Balantium striatum Monterosato, 1878:115

Hyalocylix striata Meisenheimer, 1905:17

Species: Hyalocylis striata (Rang, 1828)

The genus Hyalocylis is known to be present from the Upper Miocene - Pliocene (Ujihara 1996). One extant and several fossils species are described. The fossil genus Prehyalocylis Korobkov, 1962 is known to be present in the Middle Eocene; it seems connected to the genus Hyalocylis.

MATERIAL EXAMINED

TARA Oceans mission (2009 - 2012) $\left(39^{\circ} 53^{\prime} \mathrm{N}, 12^{\circ} 50^{\prime} \mathrm{E} ; 3^{\circ} 45^{\prime} \mathrm{N}, 14^{\circ} 15^{\prime} \mathrm{E}\right): 87$ specimens. Western Mediterranean Sea, Caribbean Sea (Virgin Islands), Pacific Ocean: 12 specimens.(ED mission 2008) Pacific Ocean , French Polynesia (14²49' S, $146^{\circ} 35^{\prime} \mathrm{W} ; 1^{\circ} 45^{\prime} \mathrm{S}, 33^{\circ} \mathrm{W}$ ), surface: 3 singular specimens

\section{DEFINITION}

Hyalocylis striata has a conical teloconch dorso-ventrally depressed with a dorsal curvature, ellipsoidal transversal section, about 30 transversal striae, peristome with thin edges and no lateral ridges. I $=6.0-9.0 \mathrm{~mm}$. The juvenile shell with conical-shaped protoconch is discarded in adults, where a blunt apex is closed by a septum, similar to Cuvierina. The two parapodia are very big in relation to the body size. They are rarely folded back into the shell; there is a ciliated area at their base that, again, resembles that of the Cuvierina. The posterior footlobe is largely reduced. The anterior margin of the mantle is lined by a single fringe as Creseis (Rampal 1975) 
and bears a long and thin balancer as well as a small triangular expansion (Fig. 1F). The pallial gland resembles that of Creseis, although a dumbbell-shaped layer, similar to the one in Cuvierina, can be found in the prismatic zone (Fig. 5D). The radular teeth have a long and thin cuspide; the trapezoidal base of the median tooth is covered with long and fine denticles (Fig.7D). In the Pacific Ocean are found singular specimens with dark marks on the edge of the parapodia (Fig.11).

\section{CLADISTIC AND MOLECULAR ANALYSES}

Cladistic: Hyalocylis striata is the sister group to the Cavolinioidea (not including Creseis). COI data set: it is the sister group to all the Cavolinioidea + Heliconoides inflata + Thielea helicoides. COI data: together with Limacina helicina, it is the sister group to the Pseudothecosomata. 28S mol. data: it is the sister group to Cuvierina. $28 \mathrm{~S}$ gene data set: it is the sister group to the Cavolinioidea (not including Creseis).

These molecular analyses also show that the singular specimens with dark marks on the parapodia are very likely to be undergoing speciation. (Figs 7E, E'; 11) (COI: 1.00/100; 28S: $1.00 / 99,1.00 / 100)$.

\section{REMARKS}

The cladistic and molecular analyses support the removal of Hyalocylis from Creseidae Rampal, 1973, a conclusion that also was previously reached for Styliola (Rampal 1975: 118, 119, 122). Indeed, Hyalocylis only shares a few features with Creseis, mostly with respect to the conical shell and the pallial complex: a single fringe and only two areas of parallelepipedic cells in the pallial gland. Other traits distinguish it from Creseidae: dorso-ventral depression, presence of a dumbbell-shaped layer of prismatic cells and the shed of the juveline shell. Using $28 \mathrm{~S}$ data, there are affinities with Cuvierina. To summarize, the phylogenetic position of Hyalocylis is difficult to ascertain and show hight instability between genes (COI, 28S) or in the same gene data (Corse et al. 2013). However, its ties with Cuvierina lineage should not be underestimated. Hyalocylis lineage could be diverged from Cuvierina lineage during the Eocene and displayed its actual morphology. Despite the incongruence of results in 285 tree, the hypothesis of a common lineage Hyalocylis-Cuvierina does not permanently be excluded. Future studies 
are necessary to clarify this probleme. Nevertheless, it is deemed appropriate, for now, to consider Hyalocylis as genus of incertae sedis.

This is not the first time that the affinities of Hyalocylis prove difficult to assess. According to Meisenheimer (1905) "Hyalocylix" originates from Creseis to give rise to Cuvierina. Bonnevie (1913) later suggested that Clio (i.e., Clio, Creseis, Hyalocylis, and Styliola) derives from Clio polita and evolves into Cuvierina. Klussman-Kolb and Dinapoli (2006), in their molecular analyses of the Opisthobranchia, found Hyalocylis basal to Cavolinia, Diacria, Cuvierina and Clio. According to Jennings et al. (2010) "the Euthecosomata were not monophyletic unless Hyalocylis striata and Limacina helicina sequences were excluded ".

Concerning the fossil genus Praehyalocylis Korobkov, 1962 (Type species: Praehyalocylis chivensis Korobkov \& Makarova, 1962) that is included in the Hyalocylis lineage, it is interesting to explain their phylogenetic relationship. This fossil is known to occur from the Middle Eocene onwards (Hodgkinson et al. 1992). Hyalocylis appeared recently (6 MY) at the Upper Miocene Pliocene (Ujihara 1996). Their relationship seems in contradiction with their morphological differences: Praehyalocylis shows a very big conical teloconch with no dorso-ventral depression, a circular transversal section, very thin and abundant transversal striation (about 80 striae) no dorsal curvature, a persistent juvenile shell and an elongated protoconch with a slight constriction. The integration of Praehyalocylis to the Hyalocylis lineage finds some support in our integrative approach to the estimation of divergence times reported in Corse et al. (2013). Hyalocylis lineage started comparatively early (Middle Eocene, 23MY) to the late emergence of Hyalocylis. It seems that Praehyalocylis, which appeared 17MY earlier, would represent a sister group to Hyalocylis with plesiomorphic ancestral caracteristics. This hypothesis thus provides an explanation for the contradiction between the belonging of Praehyalocylis and Hyalocylis to the same lineage and the gap in their respective appearance period.

\section{DISTRIBUTION}

In the TARA Oceans samples Hyalocylis striata represent $6 \%$ of the Cavolinioidea. It is often found in the inter-tropical zones of the Atlantic and Indo-Pacific Oceans. It is even more 
abundant and frequent in the Eastern Mediterranean Sea (Rampal $1970 \mathrm{~b} ; 1975)$. According to Jennings et al. (2010) "no substantial regional variation was detected among Atlantic Ocean "

\section{Superfamily CAVOLINIOIDEA Gray, 1850}

\section{Family CAVOLINIIDAE Gray, 1850}

DIAGNOSIS: dorso-ventral depression, triangular or elliptic transversal section, lateral ridges; double anterior fringe in the pallial cavity; three parallelepipedic cells areas in the pallial gland (transitional characterisitics for Cuvierina).

Genera: Cuvierina Boas, 1886, Clio Linné, 1767, Hyalaea de Blainville, 1821, Diacria Gray, 1847, Telodiacria n. gen., Cavolinia Abildgaard, 1791, Diacavolinia Spoel, 1987.

\section{PALAEONTOLOGICAL SUMMARY}

Cuvierina emerged from the Middle Eocene (Lutetian). The other genera of the Cavoliniidae Gray, 1850 emerged from the Oligocene but radiated mostly during the Miocene, long after the appearance of the earliest Cavolinioidea. Clio emerged during the Lower Oligocene (Rupelian) (35 MY). With regard to the other genera, they appeared between the Lower Miocene and the Pliocene: Fossil Gamopleura (Bellardi, 1873) (Chattian-Burdigalian); Fossil Diacrolinia Janssen, 1995 (Aquitanian-Langhian); Cavolinia (late Langhian); Diacria (late Tortonian) (Cahuzac \& Janssen 2010). Diacavolinia Spoel, 1987 emerged during the Miocene - Pliocene.Gamopleura displays a Cavolinia-like shape: large and globular teloconch, noticeable lateral ridges (at times set into a groove); however, as opposed to Cavolinia there is no lateral slits. The peristome is ellipsoidal. Diacrolinia resembles Diacria by its extremely short juvenile shell (few millimetres) that ends in a spherical or oval protoconch and its peristome with a thick lip.

\section{DEFINITION}

The parapodia and the posterior footlobe more or less developed depending on the genus.

There is a double fringe on the edge of the pallial cavity (Rampal 1975); the internal fringe has highly diversified anterior appendages: a balancer- basal lobe and a calypter-like appendage (Figs 2; 3). Cavolinia and Diacavolinia have lateral appendages very developed (Fig. 4). The 
pallial gland is composed of three areas of parallelepipedic cells (a single layered on the anterior margin and two pluri-layers connected laterally). They are separated by two areas of prismatic cells; the anterior one includes a dumbbell-shaped layer (Fig. 5F-I). Depending on the genus, the radula has a median tooth with a pointed and triangular or thin cuspide and a more or less thick and large base, which is covered on both sides with long denticles that can reach very high along the cuspide (Vayssière 1915). As the other Euthecosomata the lateral teeth are comma-shaped (Figs 8-10).

\title{
REMARKS
}

This clade represents another significant step in the cladogenesis of the Cavolinioidea. This diversifying event characterised by an increase of the teloconch volume and a dorso-ventral depression. Cuvierina is the first in the radiation: transition from the ancestral conical teloconch to an apomorphic cylindrical-subcylindrical teloconch, a dorso-ventrally depression limited to the peristome, a circular transversal section, the absence of lateral ridges, a temporary juvenile conical shell with a pear-shaped protoconch (discarded during development) and the apex of the adult teloconch closed by a septum. In the other genera lengthwise lateral ridges determine the dorsal and ventral sides. Diacria, Telodiacria, Cavolinia and Diacavolinia have open lateral slits linked by closing mechanisms. Last diversification: the peristome is protected by a dorsal lip. This dorsal lip is rather thin in Cavolinia and thick in Diacria and Telodiacria.

The cladistic and molecular analyses infer to subdivise the Cavoliniidae Gray, 1850 into four subfamilies: Cuvierininae, Cliinae, Diacriinae n. subfam., Cavoliniinae.

\author{
Superfamily CAVOLINIOIDEA Gray, 1850 \\ Family CAVOLINIIDAE Gray, 1850 \\ Subfamily CUVIERININAE (Gray, 1847) \\ Genus Cuvierina Boas, 1886
}

(Figs 2; 5; 7)

Type species: Cuvieria columnella Rang, 1827

DIAGNOSIS: Cylindric, subcylindric or bottle-shaped teloconch, bean-shaped peristome, 
deciduous juvenile shell.

Species: Cuvierina columnella (Rang, 1827), C. urceolaris (Mörch, 1850), C. atlantica Bé et al., 1972,, C. pacifica Janssen, 2005, C. cancapae Janssen, 2005, C. tsudai Burridge et al., 2016.

Cuvierina columnella (Rang, 1827)

Type species: Cuvieria columnella Rang, 1827: 322

Cleodora (Creseis) obtusa Rang, 1828: 317

Cleodora columnella Deshayes \& Edwards 1836: 434

Triptera rosea Gray, 1847: 204

Herse columnella Gistel, 1848: 174

Cuvierina columnella Boas, 1886: 134

Cuvierina columnella f. columnella Spoel, 1970: 120, Figs. 13 C, D; 19

Cuvierina columnella Rampal, 2002 : 214, Fig. 1 Cc

Cuvierina (Cuvierina) columnella Janssen, 2005: 45; Figs 8-9

Cuvierina (Columnella) pacifica Janssen, 2005: Fig.14-17

Cuvierina atlantica Burridge, 2015, Fig. 2

Cuvierina atlantica Bé et al., 1972

Type species: Cuvierina columnella f. atlantica Spoel, 1970: 120, Figs 13 A, B; 20)

Cuvierina spoeli Rampal, 2002: 214, Fig. 1Cs

Cuvierina (Cuvierina) columnella Janssen, 2005: 45, Figs 10-13

Cuvierina columnella Burridge et al., 2015, Fig.2

Cuvierina urceolaris (Mörch, 1850)

Type species: Cuvieria urceolaris Morch, 1850: 19

Cuvieria columnella Souleyet, 1852: 206

Triptera urceolaris Adams, 1853: 55

Cuvierina columnella var. urceolaris Boas, 1886:134 
Cuvierina columnella urceolaris Tesch, 1913: 38

Cuvierina columnella f. urceolaris Spoel, $1970: 120$, Figs 13 E-G ; 21)

Cuvierina urceolaris Rampal, 2002: 212, Fig. 1Cu

Cuvierina (Urceolaria) urceolaris Janssen, 2005: 55, Figs 24-27

Cuvierina urceolaris Burridge et al., 2015, Fi g. 2

Cuvierina pacifica (Janssen, 2005)

Type species: Cuvierina (Cuvierina) pacifica Janssen, 2005: 46, Fig. 15

Cuvierina columnella Rampal, 2002: 214, Fig. 1Cc

Cuvierina (Cuvierina) pacifica Janssen, 2005, Figs 14, 15, 20

Cuvierina pacifica S Burridge et al. , 2015, Fig. 2 ?

Cuvierina tsudai Burridge et al. 2016 : 5, Fig.1 A - I

Type species: Cuvierina columnella Rang, 1827: 323, pl. 45

Cuvierina columnella Rang, 1827: 323

Cuvierina columnella Spoel, $1970: 120$

Cuvierina columnella Rampal, 2002, 214, Fig.1C.c.

Cuvierina (Cuvierina) pacifica Janssen, 2005: 46, Figs 18-20

Cuvierina pacifica N Burridge, 2015, Fig.2

Cuvierina cancapae (Janssen, 2005)

Type species: Cuvierina (Urceolaria) cancapae Janssen, 2005 : 52 ; Fig. 21

Cuvierina (urceolaria) cancapae Janssen, 2005, Figs 21-23-

Cuvierina cancapae Burridge et al. 2015, Fig; 2

MATERIAL EXAMINED

TARA Oceans mission (2009 - 2012): Cuvierina columnella, C. atlantica and C. urceolaris: 21

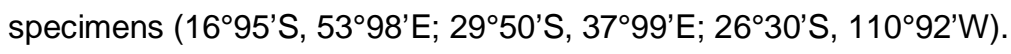

Caribbean Sea (Yucatan; Virgin Islands): 10 specimens. 


\section{DEFINITION}

Cuvierina columnella (Rang, 1827), cylindric shell, I = $7.0-8.0 \mathrm{~mm}$; C. atlantica Bé et al.,1972, subcylindric shell, I= $8.5-10.3 \mathrm{~mm}$; C. urceolaris (Mörch, 1850) bottle shaped shell, I = $5.3-$ 6.9 mm (Rampal 2002, Fig.1, Tabl. 1); C. pacifica Janssen, 2005: cylindrique-subcylindric shell, $\mathrm{I}=6,6-8,8 \mathrm{~mm}$ (Janssen 2005, Figs 14-17, 18-20); C. tsudai Burridge et al., 2015, subcylindrique, ,I = 7,2 - 8,8 mm; C. cancapae Janssen, 2005: subcylindric-bottle shell, I = 7,5 9,3 mm (Janssen 2005, Figs 21 - 23).

In the originally descriptions the larger Cuvierina is C. atlantica: I = 7,8 - 10,0 mm (Spoel 1970: 120). Paradoxally, according to Janssen (2005) and to Burridge et al. (2015, Fig. 2) the larger is C.columnella, $\mathrm{I}=11,4 \mathrm{~mm}$ (C. atlantica, $\mathrm{I}=8,4 \mathrm{~mm})$.

The peristome is bean-shaped (dorso-ventral depressed). The juvenile conical shell, circular transverse section (similar to the Creseidae teloconch) with a pear-shaped protoconch is only temporary; because it is discarded during development, the apex of the adult teloconch is closed by a septum where some remnants part of the juvenile shell can sometimes observed. The parapodia are fluffy on both sides and are almost as long as the body. The posterior footlobe is largely reduced. There is a ciliated area at the base of the parapodia (similar to Hyalocylis). A transitory organ is present at the base of the neck, called a cervical organ, which would have a function during copulation (Vayssière 1915). The pallial complexe is similar to the other Cavoliniidae (Figs 2D; 5I). It is strikingly different from those of the Creseidae. The median radular tooth is very different from the other Cavolinioidea; it is triangular, lined by short and tight denticles along the entire length and the base is flat and fairly thin (Fig. 7B). The nervous system of Euthecosomata is diversified with a tendency for the ganglia to merge; two remarkable features of Cuvierina are that the pleural ganglia can be seen externally and the existence of a second pedal commissura, as in the benthic gastropoda Actaeon (Boas 1886; Vayssière 1915; Hoffmann 1939).

\section{CLADISTIC AND MOLECULAR ANALYSES}

Cladistic: all species of the Cuvierininae are monophyletic. They are the sister group to the other Cavolinioidea (not including Creseis, Boasia, Styliola, Hyalocylis) (polytomy Styliola- 


\section{Cuvierina).}

COI data and data set (0.93/ and 0.95/): Cuvierina is the sister group to Diacria +Telodiacria + Clio. $28 \mathrm{~S}$ mol. data (0.97/): Cuvierina is the sister group to Hyalocylis. $28 \mathrm{~S}$ gene data set (1.00/82) Cuvierina is the sister group to Clio convexa + C. pyramidata. COI data and data set clearly set apart C. columnella and C. urceolaris (1.00/100). 28S data and data set (1.00/100 and 1.00/99): split between C. columnella, C. atlantica and C. urceolaris.

\section{REMARKS}

There is incongruence between the two $28 \mathrm{~S}$; consequently it is difficult to assess relationship between the other genera. Nevertheless it is clear that Cuvierina have a transitional role in the Cavoliniidae (affinities already shown concerning the pallial complexe) but only partial dorsoventral depression of the peristome.Three extant species firstly considered forma level (Spoel 1970) are previously raised to a species level: C. columnella (Rang, 1827), C. spoeli Rampal, 2002 (sysn. C. atlantica Bé et al. 1972) and C. urceolaris (Mörch, 1850) (Rampal 2002). Our molecular analyses corroborate their taxonomic species rank (Corse et al. 2013). C. cancapae and $C$. pacifica are confirmed in molecular analyses but $C$. pacifica presents two distinct taxa: C. pacifica $\mathrm{N}$ and C. pacifica S. (Burridge et al. 2015, Fig. 2). New analyses show that $C$. pacifica $\mathrm{N}$ represents a distinct species C. tsudai Burridge et al., 2016: 5, Fig. 1 A-I (Burridge et al. 2016).

Molecular clock analyses highlighted a basal position for the Indo-Pacific species bottle shaped C. urceolaris. (Corse et al. 2013): the split between C. columnella and C. urceolaris is relatively recent (Pliocene) and later than Janssen's (2005) (estimation Miocene). Their distinction in two subgenera is not supported by either morphology, anatomy or the molecular clock analyses (Corse et al 2013). The bottle shaped fossil C. Iura that appeared early in the Middle Eocene could incarnate the original phenotype characteristic to the Indo-Pacific Ocean.

To summarize, the genus Cuvierina represents the first radiation of the Cavoliniidae: transition from the ancestral conica shell to an apomorphic cylindric teloconch with a dorso-ventral depression limited at the peristome. The original morphotypes cylindric, subcylindric and bottleshaped are conserved since the Middle Eocene. 


\section{DISTRIBUTION}

In the TARA Oceans mission Cuvierina representes $6 \%$ of the Cavoliniidae; it is found between $40^{\circ} \mathrm{N}-40^{\circ} \mathrm{S}$. C. urceolaris can be typically found in the Indo-Western Pacific Ocean, nevertheless with rare mentions in the North-Eastern Pacific (Tesch 1948). C. atlantica and $C$. columnella have a widest distribution. C. atlantica is rather typical for the Atlantic Ocean but also may be found in the Indo-Pacific area (Spoel 1970; Rampal, 2002). C. columnella is the most typical for the Eastern Pacific but it also found in the Atlantic Ocean. In the Central Pacific Ocean was dradged by "La coquille" (1971) Cuvierina columnella, C. atlantica and C. urceolaris (Rampal, unpublished data).The Cuvierina genus is very rarely found in the Mediterranean Sea; it is restricted to the Alboran Sea where it is considered indicator for the Atlantic current (Rampal 1965a; 1970a; 1975). C. pacifica was found in the South Pacific Ocean and C. cancapae in the Atlantic Ocean (Janssen 2005).

\section{PALAEONTOLOGICAL SPECIES}

The Cuvierininae are occured during the Middle Eocene: Cuvierina Boas, 1886, Tibiella Meyer, 1884, Bucanoides Hodgkinson, 1992 (Lutetian); Loxobidens Hodgkinson, 1992 (late Lutetian) (Hodgkinson et al. 1992). Ireneia Janssen, 1995 (Upper Oligocene) (Cahuzac \& Janssen 2010). I would add to this list the genus Vaginella Daudin, 1800, Lower Oligocene (Rupelian), for which possible links with the Cuvierina genus were previously mentioned (Rampal 1996; 2002).

- Bucanoides, Tibiella and Loxobidens have a cylindrical and cylindrical-subcylindrical teloconch with a central bulge of various sizes and have a small depression at the back of the apertural margin. There is no lateral ridge. The peristome is roughly circular or oval and is reinforced in a platform-like structure in Loxobidens and Tibiella (Hodkinson et al 1992). The presence/absence of this platform-like feature, which is also found in some Creseidae, is very likely to bear systematic significance, as is the case for the coiled shell species with thin/tickened peristome.

- Vaginella Daudin, 1800, which appeared during the Oligocene (Rupelian) - Upper Miocene (Langhian -Tortonian) was universally belonged to the Cavoliniinae. Nevertheless phenotypical and phylogenetical affinities between Vaginella and Cuvierina were already mentioned (Rampal 
1996: 180 ; 2002: 215). Indeed, several of phenotypical features are strongly reminiscent of Cuvierina: a bottle-shaped teloconch with a central bulge, a dorso-ventrally depressed peristome (ellipsoïde to semi-circular) with a slightly concave ventral edge, a blunt apex closed by a septum, and a circular to sub-oval transverse section depending on the species. Several characteristics are a sign of a transition between Cuvierininae and Cavoliniinae: a tendency to a dorso-ventral depression of the teloconch (although only limited in Vaginella) and apparition of partial lateral ridges (along a third to half of the length in Vaginella) (dorso-ventral depression and lateral ridges run along the whole length of the teloconch in the Cavoliniinae). On the whole, this suggests a closer phylogenetical link between Vaginella and the Cuvierininae than with the Cavoliniinae, The comparison between Cuvierina inflata (Bellardi, 1873) and Vaginella depressa Daudin, 1800 is an illustration of this point of view. Further support for this interpretation is provided by the important synonymy between Vaginella and Cuvierina. To summarize, despite to lake of available anatomical data, this morphological data strongly suggests close affinities between Cuvierina and Vaginella, transitional form belong to the Cuvierininae.This point of view was indirectly accepted (p. 75) then declined (p. 100) by Cahuzac and Janssen (2010) and according to Janssen (2012: 405) Vaginella belong to the Cavoliniinae.

- Ireneia Janssen, 1995, Oligocene (Chattian) - Upper Miocene, displays an elliptic to semicircular peristome reminiscent of the Cuvierininae. However, some other features set it apart: a conical teloconch, a maximum diameter at the level of the peristome and the absence of a septum (because of a persistent apex) (Janssen 1995). As a reminder, Cuvierina has a cylindrical or bottle-shaped shell in which the maximum diameter is never at the level of the peristome and the apex, being only temporary, is closed by a septum. This suggests that Ireneia that appeared fairly late in the lineage seems to represent a plesiomorphic form sister group to Cuvierina.

- Cuvierina Boas, 1886 since its emergence in the Middle Eocene (Lutetian) until the Pliocene, during which most of the species went extinct, the Cuvierina genus diversified significantly. The earliest occurrence, in the Middle Eocene (Lutetian), is Cuvierina lura Hodgkinson, 1992, showing a bottle-shaped teloconch. The one after that is C. gutta Hodgkinson, 1992, in the 
Middle Eocene (Bartonian), with a sub-cylindrical shell (Hodgkinson et al. 1992). The following fossil species, which appeared between the Lower and Upper Oligocene, witnessed an extensive radiation between the Lower and Middle Miocene and then significant extinction in the Pliocene (Janssen 2005). They are cylindrical, sub-cylindrical or bottle-shaped.

Janssen (2005) argues that some features of $C$. lura and C. gutta suggest a Precuvierinidae: early emergence, absence of micro-ornaments, small size, and presence of juvenile shell remnants. This is not convincing for several reasons: these fossils appeared simultaneously with the other Cuvierininae fossils (see above), the micro-ornaments is a random characteristic (even according to Janssen), their size is within the range of the other genera dating from the Middle Eocene (C. gutta, I = $2.2 \mathrm{~mm}$; C. lura, I= $1.0 \mathrm{~mm}$; Bucanoides, I = $2.0-3.0 \mathrm{~mm}$; Tibiella, $\mathrm{I}=3.5-5.2 \mathrm{~mm}$ ); as for the remnant part of juvenile shell, this can be rarely found in the other species, including extant ones. Thus, Cuvierina gutta and $C$. lura meet the same criteria as the other Cuvierina.

\section{NOMENCLATURE}

Spoel (1970): Cuvierina columnella (Rang, 1827) f. columnella (Rang, 1827), C. columnella (Rang, 1827)

f. urceolaris (Mörch, 1850), C. columnella (Rang, 1827) f. atlantica nov. forma.

Bé et al. (1972): 'Forma columnella is intermediate between these formae' (Forma atlantica and Forma urceolaris) 'in having its greatest diameter between the middle and the caudal ends of the shell...Our present study is confined to C. columnella forma atlantica' (p. 49). Afterwards (p. 58) is written 'Cuvierina columnella atlantica (Spoel)': so, the taxonomically invalid C. columnella f. atlantica (ICZN) is an available subspecies, Cuvierina columnella atlantica, not at a new species (in accordance with the evaluation by Bé et al. of the three intermediate formae of Cuvierina columnella).

Rampal (2002: 214): biometrical analyses suggest a specific level; so, out of respect for the author of the originel description, this species was named Cuvierina spoeli Rampal, 2002.

Janssen (2005: 45) replaces C. spoeli by Cuvierina (Cuvierina) atlantica Bé et al.1972: "according to ICZN (1999) 15.2 \& 45.5.1, the name was validated as a specific group name by Bé et al. (1972: 58) ...Rampal (2002) rejected the name atlantica and introcuced the name spoeli for it. This, however, is not a replacement name, as Rampal designated another specimen as holotype, from a sample originating from $21^{\circ} 08^{\prime} \mathrm{S}, 55^{\circ} 11^{\prime} \mathrm{E}$ (SW Indian Ocean). This sample, a paratype of which was available to me, belongs to C. columnella, which makes the name $C$. spoeli to a junior synonym of $C$. columnella. This paratype of $C$. 
spoeli is here designated neotype of C. columnella (see below)" (Janssen 2005: 45).

Janssen suggestion that $C$. spoeli is not a species does not seem grounded (apart from the use of a sample 'available to me'). Concerning the Indian holotype locality ( South-western Indian Ocean), a border geographical zone, it is important to call back that $C$. atlantica was also found apart from the Atlantic Ocean (Rampal 2002: 214, Tabl. 2). "A geographic barrier between Indo-Pacific and Atlantic populations is unknown at present. Distribution of the two forms in the South of Africa seems to be continuous from the Indian into the Atlantic coast" (Spoel 1970: 114, 116, 118).

The molecular analyses also seem to put forward this Janssen point of view. The $C$. spoeli specific level is confirmed by our molecular analyses and the same applies to $C$. columnella and $C$. urceolaris. $28 \mathrm{~S}$ mol. data (1.00/100): $C$. urceolaris is the sister group to $C$. columnella and $C$. spoeli; $C$. spoeli is the sistergroup to $C$. columnella (Corse et al. 2013, Figs 13 - 16). As a consequence the specimen named Cuvierina spoeli is neither a paratype nor a neotype or junior synonym of Cuvierina columnella. It is a synonymous of C. atlantica.

As to the specific group name of the genus Cuvierina " a specific group takes the oldest valid species name among those of its components" (ICZN). So the specific group name of the genus Cuvierina is columnella, not atlantica.

\author{
Superfamiy CAVOLINIOIDEA Gray, 1850 \\ Family CAVOLINIIDAE Gray, 1850 \\ Subfamily CLIINAE Jeffreys, 1869
}

(Figs 2; 5; 8)

DIAGNOSIS: complet dorso-ventral depression of the triangular teloconch, lateral ridges, triangular or ellipsoidal transversal section, semi-circular posterior footlobe.

Genera: Clio Linnaeus,1767, Hyalaea de Blainville, 1821

Genus: Clio Linnaeus, 1767: 1094

Type species: Clio pyramidata Linnaeus, 1767: 1094

Hyaloea caudata Roissy, 1805: 75

Cleodora pyramidata Peron \& Lesueur, $1810: 66$

Hyalea lanceolata Cuvier, 1817: 381

Hyalaea retusa de Blainville, 1821: 81 
Clio pyramidata Gray, 1850: 12

Balantium australe Gray, 1850: 15

Clio (Clio) pyramidata Pelseneer, 1888: 63

Clio (Euclio) pyramidata Bonnevie, 1913: 23

Euclio pyramidata Tesch, 1946: 14

Proclio subteres Hubendick, 1951: 3

Species: Clio chaptalii Gray, 1850, Clio polita (Pelseneer, 1888) , Clio recurva (Childern, 1823),

C. pyramidata Linnaeus, 1767: C. p. lanceolata (Lesueur, 1813), C. p. sulcata (Pfeffer, 1879),

C. p. martensii (Pfeffer, 1880), C. convexa (Boas, 1886), C. antarctica Dall, 1908, C. excisa

Spoel, 1963; C. piatkowskii Spoel et al., 1992.

Genus: Hyalaea de Blainville, 1821: 9

Type species: Hyalaea cuspidata Bosc, 1802: 2415 (by original

designation)

Hyaloea cuspidata Roissy, 1805: 74

Hyalea cuspidata Bosc, 1817: 433

Cleodora cuspidata Quoy \& Gaimard, 1832: 384

Clio cuspidata Gray, 1850: 13

Clio (Clio) cuspidata Pelseneer, 1888: 66

Clio (Euclio) cuspidata Bonnevie, 1913: 22

Euclio cuspidata Tesch, 1946: 14

Clio cuspidata Spoel, 1967: 73

Species: Hyalaea cuspidata (Bosc, 1802) [(syn. Clio cuspidata (Bosc, 1802)]

MATERIAL EXAMINED

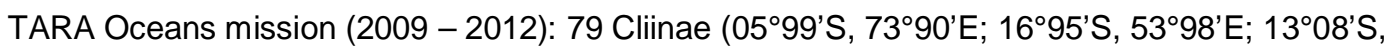
$\left.46^{\circ} 97^{\prime} \mathrm{E} ; 39^{\circ} 89 \mathrm{~N}, 12^{\circ} 24 \mathrm{E}\right)$. 
Mediterranean Sea, Caribbean Sea (Yucatan; Virgin Islands): 15 Cliinae.

\section{PALAEONTOLOGICAL SUMMARY}

According palaeontological data the Cliinae appeared from the Lower Oligocene (35 MY), 37.8 MY using a pairwise genetic distance-based method to estimate divergence times by Corse et al. (2013). Clio then witnessed an important diversification at the species or infra-species levels during the Middle Miocene (Langhian). Most of the extant taxa appeared during the late Pliocene (Cahuzac \& Janssen 2010).

\section{DEFINITION}

The Cliinae have a pyramidally shaped teloconch with a dorsal curvature of varying degree and a triangular or ellipsoidal transversal section. There are angular or flat lateral ridges but no lateral slits nor closing mechanism. In some species, the teloconch is transversally striated. The peristome is wide and its dorsal and ventral lips are not bent. There are longitudinal dorsal ribs which are absent in Clio polita. Hyalaea cuspidata has long dorsal and lateral spines. The protoconch is characteristic: Hyalaea cuspidata and Clio polita have a spherical protoconch (with ring in this last); the other Cliinae rather have an oval protoconch. The posterior footlobe is semi-circular. The pallial cavity is ventral; it is lateral in Clio polita. The fringe and the anterior mantle appendages and the pallial gland are comparable to the other Cavoliniidae but they are reduced in Clio polita. In the pyramidata group the right-hand half of the anterior external fringe of the mantle is folded (Fig. 2C). The median teeth of the radula have different forms; $C$.

pyramidata have a trapezoidal-quadrangular base with numerous and long denticules and a thin cuspide (Fig. 8 A); Hyalaea cuspidata have a triangular base with short denticules and a triangular curved cuspide (Fig. 8D). Clio polita can be also distinguished from the other Cliinae by a symmetrical nervous system with fused visceral and pedal ganglia (Bonnevie 1913; Tesch 1946; Spoel 1967).

\section{CLADISTIC AND MOLECULAR ANALYSES}

The cladistic analysis includes: Clio convexa, C. recurva, C. chaptalii, C. pyramidata, Hyalaea cuspidata and Clio polita. Unfortunaly for the molecular analyses the taxonomic sampling and 
the phylogenetic trees resolution are only obtained for Clio pyramidata, C. convexa and Hyalaea cuspidata.

Cladistic: the Cliinae are monophyletic and they are the sister group to the Diacriinae n. subfam; Clio polita is the sister group to Clio recurva and to Clio chaptalii.

Molecular analyses. COI: the Cliinae are monophyletic; Hyalaea cuspidata is the sister group to the new monophyletic clade Clio pyramidata + C. convexa; the Cliinae are the sister group to Diacria trispinosa + D. major. $28 \mathrm{~S}$ gene data set: the Cliinae are not monophyletic (in relation to Hyalaea cuspidata); Hyalaea cuspidata is the sister group to Styliola subula, they are the sister group to the Cuvierininae and to the other Cliinae; $28 \mathrm{~S}$ mol. data: the Cliinae are not monophyletic; Hyalaea cuspidata is the sister group to Styliola subula and they are the sister group to other the Cavoliniidae (except the Creseidae). According to Jenning et al. (2010) in COI Clio recurva is geneticaly similar in the Eastern and Southern Atlantic Ocean.

REMARKS.

In $\mathrm{COI}$ the Cliinae are monophyletic; in $28 \mathrm{~S}$ they are not monophyletic in relation to the inconsistant position of Hyalaea cuspidata.Two species Clio polita and Hyalaea cuspidata stand out as very entity in the Cliinae.

Clio polita Pelseneer, 1888

The present limited data in the phylogenetic trees resolution do not permit to propose a generic break for Clio polita. Nevertheless this bathypelagic species presents some plesiomorphic characteristics especially the lateral pallial cavity, the reduced anterior pallial fringes, flat and blunt parapodia and the symmetrical nervous system with fused visceral and pedal ganglia. Despite the deficient molecular analyses, the morphological, anatomical and ecological characteristics suggest that this species is the witness of an ancestral plesiomorphic state of an hypothetic Cliniinae's common ancestor.This bathypelagic species could have emerged recently from an ancient lineage and would have retained some of its features. This hypothesis could be tested using the integrative approach to the estimation of divergence times and molecular analyses. 
Hyalaea cuspidata Bosc, 1802: 241 (Figs 2B; 5F)

The molecular analyses support a genus break for this species before named Clio cuspidata.

28S: the Clinae are not monophyletic in relation to the

inconsistante position of Hyalaea cuspidata. It also can be

distinguished from the orher Cliinae by several features: lateral and

dorsal spines of the teloconch, spherical protoconch with a terminal spine, characteristic intestin appendage, exclusive structure unique in the family (Tesch 1946; Spoel 1967); one dorsal and two bilobed lateral appendages; left lateral bilobed expansion (Rampal 1965b): calypter like appendage homologous? (Fig. 2B).

Despite his relative phenotypical stability, different sequences "were detected between regions for Hyalaea cuspidata (SE Atlantic vs. Southern Ocean)" (Jennings et al. 2010).

DISTRIBUTION OF THE CLIINAE

In the Tara Oceans samples the Cliinae represent $22 \%$ of the Cavoliniidae. Clio convexa is a characteristic Indo-Pacific Cliinae. A subspecies Clio convexa cyphosa Rampal, 2002 was identified in the Red Sea.

The pyramidata group is polytypic and polymorphic (Spoel 1963, 1967, 1969a; Rampal 1975, 2002). Clio pyramidata lanceolata: $62 \%$ of the Cliinae found during Tara Oceans mission. It is circumglobal. C. p. pyramidata is in the border repartition of C. p. lanceolata. In the Southern Atlantic Ocean the pyramidata group displays high variations: C. p. sulcata; C. p. martensii. Some taxa were raised to the species level: $C$. convexa, $C$. antarctica; $C$. excisa. Hyalaea cuspidata is present but not abundant in all the oceans (11,4\% Clinae). It was found during the Tara Oceans mission in the Eastern Mediterranean Sea, Northern Indian Ocean, Atlantic Ocean (Eastern South Atlantic, Central South Atlantic, Western South Atlantic, and Western North Atlantic).

C. recurva and C. chaptalii have a discontinuous global distribution. The bathypelagic species Clio polita is caracteristic of the Atlantic Ocean. 


\section{NOMENCLATURE}

Clio polita Pelseneer, 1888 was alternately named falcata and polita.

Cleodora falcata Pfeffer, 1880: 96 (priority page) [Clio falcatum Meisenheimer 1905b: 422; Clio falcata Meisenheimer 1906: 107; Clio (Euclio) falcata Bonnevie, 1013: 20)].

Clio polita Pelseneer, 1888: 60 [Clio polita Meisenheimer 1905a: 20; Clio (Balantium) polita Johnson 1934:152; Euclio polita Tesch 1946: 15; Clio polita Spoel 1967: 75].

According to Tesch (1946) 'Meisenheimer (1905b) objected to the use of the name of polita on account of it being only a manuscrit designation, so that the name falcata Pfeffer was restored by them'. However since Johnson (1934) is generaly choice polita.

\section{Superfamily CAVOLINIOIDEA Gray, 1850 \\ Family CAVOLINIIDAE Gray, 1850 \\ Subfamily DIACRIINAE n. subfam.}

(Figs 2; 5; 8)

DIAGNOSIS: more or less globular teloconch with lateral ridges and slits, peristome with a thickened short dorsal lip, rudimentary closing system, long juvenile shell (persistant or deciduous) with flat lateral ridges; semi-circular posterior footlobe.

Genera: Diacria Gray, 1847 and Telodiacria n. gen.

They are known to be present from the Miocene (Tortonian) - Pliocene.

Genus: Diacria Gray, 1847

Type species: Hyalaea trispinosa de Blainville, 1821: 82

Hyalea trispinosa Rang, 1829: 115

Diacria trispinosa Gray, 1847: 203

Cleodora infundibulum Wood, 1842: 459

Hyaloea trispinosa Verany, 1853: 380

Cavolinia trispinosa Pelseneer, 1866: 346

Cleodora compressa Adams, 1853: 52 
Cavolinia trispinosa (part) Pelseneer, 1866: 346

Hyalaea (Diacria) trispinosa Monterosato, 1875: 50

Pleuropus trispinosa Pfeffer, 1879: 236

Cavolinia (Diacria) trispinosa (part) Dall, 1889: 82

Diacria trispinosa Meisenheimer, 1905 a: 2

Species: Diacria trispinosa (de Blainville, 1821), D. major (Boas, 1886), D. rampali Dupont, 1979, D.

maculata Beeker \& Spoel, 1988, D. piccola Bleeker and Spoel, 1988, D. gracilis Rampal, 2002.

Genus: Telodiacria n. gen.

Type species: Hyalaea quadridentata de Blainville, 1821: 81

Hyalea quadridentata Deshayes \& Edwards, 1836: 41

Cavolina quadridentata Gray, 1850: 8

Hyalea costata Pfeffer, 1880: 91

Cleodora pygmaea, Boas, 1886: 84

Cavolinia quadridentata Peck, 1894: 453

Cavolinia (Diacria) quadridentata Tesch, 1904:36

Diacria quadridentata Meisenheimer, 1905a: 29

Species: Telodiacria quadridentata (de Blainville, 1821) n. comb., T. costata (Pfeffer, 1879) n.

comb., T. danae Spoel, 1968 n. comb., T. erythra Spoel, 1971 n. comb., T. schmidti Spoel, 1971 n. comb.

MATERIAL EXAMINED

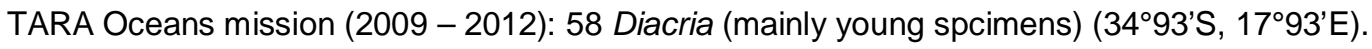

Caribbean Sea (Yucatan; Virgin Islands): 13 Diacria.

TARA Oceans mission (2009 - 2012): 132 Telodiacria n. gen (mainly young specimens)

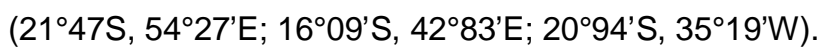

Caribbean Sea (Yucatan; Virgin Islands): 31 Telodiacria n. gen. 


\section{CLADISTIC AND MOLECULAR ANALYSES}

Cladistic: Diacriinae and Cavoliniinae represent two distinct lineages. Diacria trispinosa and

Telodiacria quadridentata $\mathrm{n}$. comb. form a new clade that is the sister group to the Cliinae.

COI data and data set: Diacriinae and Cavoliniinae are not monophyletic; Diacria is the sister

group to the Cliinae and Telodiacria is the sister group to Diacria + Cliinae. 28S data and data

set (1.00/100): Diacria is the sister group to Telodiacria and they form a monophyletic subfamily

Diacriinae; $28 S$ mol. data (0,97/): the Diacriinae are the sister group to Cuvierina andHyalocylis.

Despite the incongruence, these analyses support the new genus Telodiacria and justify the new subfamily Diacriinae.

Genus: Diacria Gray, 1847

Type species: Hyalaea trispinosa de Blainville, 1821:81

DIAGNOSIS: flat teloconch, long lateral spines, persistant juvenile shell, spheric protoconch.

\section{DEFINITION}

Diacria has a long, large and flat shell. It includes a large and flat teloconch (ellipsoidal section) with lateral spines and a persistant juvenile shell: I (total shell) $=7.06-11,00 \mathrm{~mm} ;$; (teloconch) $=5.44-8.69$

$\mathrm{mm} ; \mathrm{w}$ (spines) $=5.97-11.08 \mathrm{~mm} ; \mathrm{h}$ (teloconch) $=2.05-2.91 \mathrm{~mm})$. The very long and narrow juvenile shell has flat lateral ridges and a spheric protoconch. This shell is hyaline and sometimes more or less brown. The median radular teeth have a large and short base with short denticules and triangular curved cuspide (Fig. 8E, F).

The trispinosa group is polytypic and polymorphic. D. trispinosa (de Blainville, 1821): D. t. trispinosa (de Blainville, 1821), D. t. atlantica Dupont, $1979(\mathrm{I}=9.66-11 \mathrm{~mm})$, D. t. heterocolorata Rampal, 2002 (I = 7.06 mm); D. major (Boas, 1886) (I teloconch = 7, 40 - 8, 69 $\mathrm{mm}$ ) (the juvenile shell is often discarded); $D$. rampali Dupont, $1979(\mathrm{I}=8.72-10.48 \mathrm{~mm}) ; D$. maculata Bleeker and Spoel, 1988; D. piccola Bleeker and Spoel, 1988; D. gracilis Rampal, $2002(\mathrm{I}=8.86-10,10 \mathrm{~mm})$ (Rampal 2002).

MOLECULAR ANALYSES

$\mathrm{COI}$ and 28S: the Diacria lineage is monophyletic. These analyses support the taxonomic rank 
of three species (there is no sequence available for D. gracilis). $28 \mathrm{~S}$ data (1.00/100): Diacria trispinosa is the sister group to $D$. rampali $+D$. major. $28 S$ data set $(0,99 / 96): D$. rampali is the sister group to $D$. trispinosa + D. major (COI data: 0 sequence).

According to Jennings et al. (2010) D. trispinosa specimens "from widely separated ocean basins were geneticaly similar (E Atlantic and SE Indian); specimens with "sequence differences were detected between regions for D. major (NW Atlantic vs. SE Indian)". Genus: Telodiacria n. gen.

Type species: Hyalaea quadridentata de Blainville, 1821: 81.

ETYMOLOGY: fets the last development phase telo.

DIAGNOSIS: globular teloconch, lateral spine absent, deciduous juvenile shell, oval protoconch, apex closed by a septum.

\section{DEFINITION}

Main features: globular hyaline or brown teloconch, absence of lateral spines, presence of a deciduous juvenile shell with an oval protoconch, apex closed by a septum. There are three or five dorso-longitudinal ribs more or less hilly; the peristome has a thickened dorsal lip and transversal striae; the ventral side have transverse striae. Near the lateral fringes there is a vacuolised cells area (Fig. 2H). Telodiacria quadridentata n. comb.: I $=2.5-3.0 \mathrm{~mm}$; hyaline shell, tickened peristome sometimes brown border; 5 longitudinal slightly swollen dorsal ribs; less proeminent transversal striae.T. costata n. comb.: I = $3.5-4.0 \mathrm{~mm}$; solide and ticker shell; hyaline sometimes brown shell; 5 deep long and sharp well developed dorsal ribs; well proeminent transversal striae. $T$. danae $n$. comb.: I $=1.60-1,98 \mathrm{~mm}$; hyaline shell; 3 faintly swollen more or less short ribs; transversal striae. We have no observed T. erythra Spoel 1971 n. comb. and T. schmidti Spoel 1971.

\section{MOLECULAR ANALYSES}

Limited results because there is a minority of adult specimens. COI $(1.00 / 94,1.00 / 95)$

Telodiacria is monophyletic; one young unspecified specimen is the sister group to $T$.

quadridentata n. comb. and to T. danae n. comb. $28 \mathrm{~S}$ data set: $T$. danae n. comb. is the sister group to two youg unspecified specimens. 


\section{DISTRIBUTION}

In the Tara Oceans expedition Diacria represents $16.4 \%$ of the Cavoliniidae. D. trispinosa atlantica: Nord Atlantic $\left(30^{\circ}-60^{\circ}\right)$. D. t. trispinosa: circumglobal $\left(35^{\circ} \mathrm{N}-35^{\circ} \mathrm{S}\right)$ (other taxa were certainly assimilated to this specie). D. rampali: circumglobal $\left(20^{\circ} \mathrm{N}-35^{\circ} \mathrm{S}\right)$. D. gracilis:

Western Pacific Ocean. D. major is rarely found in all the oceans.

Telodiacria (majority of young specimens) represents $20.6 \%$ of the Cavoliniidae. T.

quadridentata n. comb. and T. costata n. comb.: Indo-Pacific area. T. danae n. comb. :

circumglobal distribution. T. erythra Spoel, 1971: Red Sea and Western Indian Ocean.

T. schmidti Spoel 1971n. comb. Easten Pacific Ocean.

\section{Superfamily CAVOLINIOIDEA Gray, 1850 \\ Family CAVOLINIIDAE Gray, 1850 \\ Subfamily CAVOLINIINAE Gray, 1850}

(Figs 3; 5)

DIAGNOSIS: more or less globular teloconch with ridges and slits, long peristome with bent dorsal lip, well developed closing system, caracteristic dorsal ribs, juvenile shell absent, wide posterior foot lobe.

Genera: Cavolinia Abildgaard, 1791 and Diacavolinia Spoel, 1987.

The Cavoliniinae can be found from the Miocene (Langhian) onwards

Genus: Cavolinia Abildgaard, 1791: 175.

Type species: Cavolinia tridentata (Niebuhr, 1775)

Anomia tridentata Niebuhr, 1775: 124

Cavolinia natans Abildgaard, 1791: 175

Hyalaea cornea Lamarck, 1801: 139

Haloea tridentata Roissy, 1805: 73

Hyalea tridentata Lamarck, 1816: 13

Cleodora strangulata Deshayes, 1823: 203 
Pleuropus pellucidus Eschscholtz, 1825: 735

Cavolinia (Orbignyia) inflexa Adams, 1859: 45

Cavolinia (Cavolinia) tridentata Tesch, 1904: 37

Cavolinia tridentata Spoel, 1967: 94

Species: Cavolinia gibbosa (d'Orbigny, 1836) C. globulosa (Gray, 1850), C. inflexa (Lesueur, 1813), C. tridentata (Niebuhr, 1775), C. uncinata (Rang, 1829).

Genus : Diacavolinia Spoel, 1987: 78

Type species: Hyalaea longirostris de Blainville, $1821: 81$

Cleodora strangulata Deshayes, 1823 : 204

Hyalea laevigata Deshayes \& Edwards, 1836: 423

Cavolina longirostra Gray, 1850: 8

Pleuropus laevigata Adams, 1858: 611

Cavolinia longirostris Pelseneer, 1888: 79

Cavolina (Cavolina) longirostris Dall \& Simpson, 1900: 361

Cavolinia(Cavolinia) longirostris Tesch, 1904: 41

Diacavolinia longirostris Spoel, 1987: 78

Species: Diacavolinia longirostris (de Blainville, 1821), D. angulosa Gray, 1850, D. strangulata (Deshayes, 1823), D. limbata (d'Orbigny, 1836), D. flexipes Spoel, 1971, D. mcgowani Spoel, 1973. Sixteen species are described by Spoel et al. (1993): D. aspina, D. atlantica, D. bandaensis, D. bicornis, D. constricta, D. deblainvillei, D. deshayesi, D. elegans, D. grayi, D. ovalis, D. pacifica, D. robusta, D. souleyeti, D. striata, D. triangulata, D. vanutrechti.

MATERIAL EXAMINED

TARA Oceans mission (2009 - 2012) : 63 specimens $\left(14^{\circ} 59^{\prime} \mathrm{N}, 69^{\circ} 98^{\prime} \mathrm{E} ; 06^{\circ} \mathrm{O} 3^{\prime} \mathrm{N}, 7^{\circ} 89^{\prime} \mathrm{E}\right.$; 


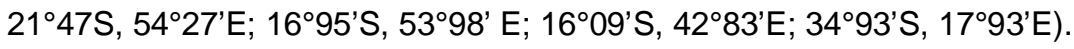

Western Mediterranean Sea, Caribbean Sea (Yucatan; Virgin Islands): 66 specimens.

\section{DEFINITION}

The Cavoliniinae displays a more or less globular teloconch with an ellipsoidal transversal section; the peristome have a round and curved dorsal lip (straigth and pointed in Cavolinia inflexa, beak-like gutter stucture in Diacavolinia). There are longitudinal lateral slits with an important closing mechanism (two mecanisms in Diacavolinia). The comma-shaped protoconch is in line with the teloconch without clear demarcation; in Diacavolinia there is a discarded protoconch and the apex is closed by an irregular slit (no septum) (Spoel et al. 1993). Cavolinia. inflexa is lower larger near the lateral spines and longer posteriorly. The dorsal ribs number is generaly different in the Atlantic and Indo-Pacific area: inflexa group ( 3 or 1 ribs), gibbosa group (7 or 5 ribs), uncinata group ( 3 or 5 ribs). The parapodia are very elongated and the posterior footlobe is short but very large. The anterior appendages of the mantle are similar to the other Cavoliniidae; the Diacavolinia species and Cavolinia globulosa also have two anteroventral trilobed expansions sometimes deciduous (Fig. 3C, E). There are long and retractile lateral appendages (Fig. 4). The pallial gland is similar to the other Cavoliniidae (Fig. 5H). The median teeth of the radula have a triangular base with long denticules and a triangular curved cuspide (Figs 9; 10). Diacavolinia species have separate genital aperture (Meisenheimer, 1905).

\section{CLADISTIC AND MOLECULAR ANALYSES}

In these analyses was named Diacavolinia or Diacavolinia longirostris seven unspecified specimens (Corse et al. 2013).

Cladistic: Cavolinia Gray, 1850 and Diacavolinia Spoel, 1987 form a monophyletic group: Cavoliniinae Gray, 1850.

COI data and data set: the Cavoliniinae are not monophyletic because Cavolinia inflexa is basal to a clade composed of the other straight shell Euthecosomata (not including Hyalocylis). COI data $(0,97 /, 0,98 /)$ : Diacavolinia (Mozambique Channel) is nestled within Cavolinia labiata (d'Orbigny, 1836) and within Cavolinia sp. (South-Western Indian Ocean). 28S mol. data and 
gene data set (Figs 15, 16): the Cavoliniinae are monophyletic; these molecular analyses also show affinities of Diacavolinia with some Cavolinia (1.00/98, 1.00/90): Diacavolinia (Carribean Sea) is the sister group to Cavolinia globulosa (Gray, 1850) (North Indian Ocean); this group forms a clade monophyletic with the other Cavoliniinae.

\section{REMARKS}

Diacavolinia was validated by DNA barcoding (Mass et al. 2013); indeed it has some distinct caracteristics (deciduous protoconch, two closing mechanisms, and distinct genital orifices). Nevertheless the molecular analyses show affinities Diacavolinia with Cavolinia labiata, C. globulosa and Cavolinia sp.: the genus Diacavolinia nestled within these Cavolinia seems invalidated. Nevertheless it is difficult to explain the different topologies in this subfamily (monophyly or polyphyly), as well as the aberrant position of species to the same group (Cavolinia inflexa and C. labiata) and the position of Cavolinia inflexa (sister group of the entire straight shaped Euthecosomata (except Hyalocylis). Further analyses are needed to help understanding these issues. The genus Diacavolinia is therefore at present maintained.

\section{DISTRIBUTION}

In the TARA Oceans samples the Cavoliniinae represents $18 \%$ of the Cavoliniidae.

\section{Gibbosa group}

Cavolinia gibbosa (d'Orbigny, 1836): South-Western Indian Ocean, Mozambic Channel and Benguela Current (South-Eastern Atlantic Ocean). Cavolinia flava (d'Orbigny, 1836): all over Atlantic Ocean and two rare particular situations: an exceptional incursion into the Western Mediterranean Sea near Gibraltar (Atlantic current indicator) and few presence in the NorthEastern Pacific near Panama: pre-isthmatic Atlantic palaeo-indicator; this last area represents a faunistic entity in the Pacific Ocean (Rampal 2002; 2014). Cavolinia plana (Meisenheimer, 1905 ) is a characteritic Indo-Pacific species. It is found in the Indo-Austral Archipelago (Tesch 1904), troughout the Indo-Western Pacific (Rampal 1975) and only rarely in the South-Eastern Pacific (Meisenheimer 1905). C. gibboides Rampal, 2002 is located in the Eastern Mediterranean Sea - South-Tyrrhenian Sea (Rampal 1970b). Unfortunally our molecular analyses did not yield any result for C. gibboides (Corse et al. 2013). . 
Inflexa group

Cavolinia inflexa imitans (Pfeffer, 1880): cicumglobal distribution. Cavolinia inflexa inflexa (Lesueur, 1813): border of the C. i. imitans distribution. Cavolinia labiata (d'Orbigny, 1836): Indo- Pacific distribution, Mozambique Channel with incursion in the South Eastern Atlantic Ocean. The sporadic presence of Cavolinia inflexa in the North-Eastern Pacific Ocean can to touch on the pre-isthmatic palaeo-indicator (Rampal 2002). Cavolinia labiata and C. inflexa (1.00/99) are found in a same station without hybridization.

Tridentata group

Cavolinia tridentata (Forskal, 1775) has a special biogeography. It is composed of at least by nine infraspecific members: tridentata, bermudensis, dakarensis, atlantica, kraussi, danae, teschi, affinis, occidentalis (Pfeffer 1880; Boas 1886; Schiemenz1906; Mac Gowan 1960; Spoel 1974; Rampal 1975). Despite a vast polymorphism, two morphological tendencies can be observed. One linked to tridentata (large worldwide repartition) and one to affinis (d'Orbigny, 1836) (almost localised to the Eastern Pacific Ocean). However, a projection of correspondence analyses shows a succession of affinities between the populations of different oceans. This results in a circumglobal cline with a belt of hybrid populations in the South-Eastern Pacific Ocean (Rampal 1975). Each area has a characteristic phenotype but the morphotype usually shows affinities with the ones from neighbouring areas as a clinal variation.

Uncinata group

This tropical group is present in the entire ocean (Mediterranean Sea?). There are Indo-pacific and Atlantic entities. Spoel (1969) described three taxa: Cavolinia uncinata uncinata (Rang, 1828) $(\mathrm{I}=6.97 \mathrm{~mm})$ and C. u. roperi Spoel, $1969(\mathrm{I}=4.48 \mathrm{~mm})$ from the Atlantic Ocean; C.$u$. pulsata Spoel, $1969(\mathrm{I}=8.14 \mathrm{~mm})$ from the Indian Ocean. These taxa differ by the dorsal ornementation: The Atlantic specimens have three dorsal ribs (the two laterals very lightly deprimed on the middle); the indo-pacific specimens have five dorsal ribs; the Indian specimens are the biggest (Rampal 1979). According to Jennings et al.(2010) in COI there is no subtantial regional variation among Atlantic locations for $C$. uncinata but sequence differences were detected between different regions "(Atlantic vs.SE Indian)".

Longirostris group 
The polymorphic and polytypic recent genus Diacavolinia is present in all the oceans (rare in the Mediterranean Sea). According to Spoel et al. (1993) there are characteristic repartitions:

Atlantic Ocean: D. atlantica, D. deblainvillei, D. ovalis, D. deshayesi, D. constricta, $D$.

strangulata, D. longirostris, D. limbata.

Indian Ocean: D. bicornis, D. souleyeti, D. striata, D. aspina.

Red Sea: D. flexipes.

Pacific Ocean: D. pacifica, D. vanutrechti, D. triangulata, D. robusta, D. mcgowani,

Malaisie: $D$. vanutrechti, $D$. elegans, $D$. bandaensis.

Atlantic, Indian and Pacific Ocean: D. angulos.

Cavolinia globulosa (Gray, 1850): Indo-Pacific species.

\section{NEW CLASSIFICATION (extant taxa)}

THECOSOMATA de Blainville, 1824

EUTHECOSOMATA Meisenheimer, 1905

Family Limacinidae Gray, 1847

Genus Limacina Bosc, 1817; Limacina helicina (Phipps, 1774)

Family Heliconoididae n. fam.

Genus Heliconoides d'Orbigny, 1835; Heliconoides inflata (d'Orbigny, 1835)

Family Thieleidae n. fam.

Genus Thielea Strebel, 1908; Thielea helicoides (Jeffreys, 1877)

Superfamily CAVOLINIOIDEA Gray, 1850

Family Creseidae Rampal, 1973

Genus Creseis Rang, 1828; Creseis virgula (Rang, 1828)

Genus Boasia Dall, 1889; Boasia chierchiae (Boas, 1886) n. comb. 
Family Cavoliniidae Gray, 1850

Subfamily Cuvierininae Gray, 1847

Genus Cuvierina Boas, 1886; Cuvierina columnella (Rang, 1827)

Subfamily Cliinae Jeffreys, 1869

Genus Clio Linnaeus, 1767; Clio pyramidata Linnaeus, 1767

Genus Hyalaea de Blainville, 1821; Hyalaea cuspidata Bosc, 1802

Subfamily Diacriinae n. subfam.

Genus Diacria Gray, 1847; Diacria trispinosa (de Blainville, 1821)

Genus Telodiacria n. gen.; Telodiacria quadridentata (de Blainville, 1821) n. comb.

Subfamily Cavoliniinae Gray, 1850

Genus Cavolinia Abildgaard, 1791; Cavolinia tridentata (Niebuhr, 1775)

Genus Diacavolinia Spoel, 1987 ; Diacavolinia longirostris (de Blainville, 1821)

Genera Incertae sedis

Genus Styliola Gray, 1850; Styliola subula (Quoy \& Gaimard, 1827)

Genus Hyalocylis Fol, 1875; Hyalocylis striata (Rang, 1828)

\section{Phylogenetic hypotheses}

Based on morphological and anatomical data of the Thecosomata Euthecosomata, two hypotheses for the appearance of the straight shell were proposed: single appearance for the Cavolinioidea Gray, 1850 from a single spiral shell (Boas 1886, Pelseneer 1888, Meisenheimer 1905, Bonnevie 1913) or two independent appearance for the Creseidae Rampal, 1973 and the Cavoliniidae Gray, 1850 from two spiral shell lineages Limacina Bosc,1817 and Thielea Strebel, 1908 which have a same hypothetical benthic ancestor lineage (Rampal, 1973).

Our recent cladistic and molecular analyses present two hypotheses. The analyses in COI tree support the double emergency: the straight shell species could likely have appeared twice independantly with a reversion in the lineage Thielea / Heliconoides to explain the coiled shell observed in these genera (Corse et al. 2013). The double emergency also was shown in the COI 
tree by Jennings et al. (2010) (these authors do not offer any phylogenetical conclusion on account of 'their poor taxonomic sampling'). However this scenario was not adopted because it is the less parsimonious: the unwinding of the spiral shell species is homoplasic. It is the less informative for the older divergences. COI showed a lack of phylogenetic signal to infer Euthecosomata relationships (similar problem for other Mollusca).Therefore this hypthesis of the double emergency was declined (Corse et al.2013).

The analyses in $28 \mathrm{~S}$ / morphological data also propose the monophyly of the Cavolinioidea Gray, 1850: the straight shell species originated from a unique coiled shell ancestor that subsequently evolved into a straight conical morphotype belonging to the genus Creseis ancestral to the more complex straight shells of the Cavoliniidae Gray, 1850. This hypothesis is the most parsimonious analysis: it includes the unwinding in one time, it is the most informative for older divergence and it is more reliable and congruente with palaeontological data for revolving the deep nodes. We have kept this hypothesis of the monophyly (Corse et al. 2013). Nevertheless the incongruence between gene trees could also be the result of incomplete data for reconstructing phylogenies. Therefore these conclusions require some reserves and needs further investigations (Corse et al. 2013).

The spiral shell species notably, were considered neotenic organisms derived from spiral benthic ancestors (Lemche 1948; Huber 1993), hypothesis not fully accepted notably by Lalli and Gilmer (1989).

The transition between the spiral shell forms and the straight ones is illustrated by the existence of partially unwounding fossils Camptoceratops Wenz, 1923 and Sphaerocina Jung, 1971. This transition performed by a $180^{\circ}$ twist of the trunk relative to the head, and an unwinding of the visceral mass (Boas 1886) was observed to some recent species during the ontogenesis (Fol 1875). The Euthecosomata with spiral shell are known to be present from Upper PaleoceneLower Eocene (Watelet \& Lefèvre 1885). The first with straight shell is conical that is still in the first process unwinding spiral shell; it emerged during the Lower Eocene (Hodgkinson et al. 1992; Curry 1965). The hypothesis for the impact of this macro-unwinding of the spiral shell (which have prismatic and crossed lamellar aragonitic fibres) over the microstructural aragonitic straight shell can be seen in their spiral aragonitic microstructure (Rampal 1975). This spiral 
microstructure is already present in the partially unwound fossil Camptoceratops priscum

(Gowin-Austen, 1925) (Curry \& Rampal 1979) and signs of it can be observed in the apex protoconch of Heliconoides inflata (Glaçon et al. 1994, pl. 3, figs 1-9) and in the apex of Limacina retroversa (Fig. 6F); this spiral microscruture in the protochonch seems to anticipate the macro-unwinding. In the meroplanktonic veligers of some benthic Tectibranch molluscs it is observed the same aragonitic structure (Richter 1976). According to Haszprunar (1985) the structure of the Euthecosomata illustrates the paedomorphic aspect of the shell's long development. 


\section{DISCUSSION}

The emergence of the holoplanktonic Euthecosomata from benthic Gastropoda occurred through successive radiations from the Upper Paleocene - Lower Eocene until the Pliocene. These events involved deep and important morphological and anatomical changes: the acquisition of swimming organs in the spiral shell Euthecosomata and then transition to a straight shell, which later was gradually optimised. Some taxa became extinct or their diversity decreased during the Tertiary era, however, interestingly, Limacina Bosc, 1817, Creseis Rang, 1828 and Cuvierina Boas, 1886 are always present amongst the earliest genera (Eocene). The present study gave an account of these diversifying events. Moreover, a discriminating between phylogenetic hypotheses and a new systematic of the Euthecosomata was submitted. Two phylogenetic hypotheses were originally considered. The first one proposes a double emergence of straight shell species from two separate lineages of spiral shell ancestors (Rampal 1973). According COI tree there is the double emergency. However $28 \mathrm{~S}$ tree did not support this scenario wich is the less parsimonius; the second hypothesis we have kept assumes the monophyly of Euthecosomata (Corse et al. 2013). The congruence of our results from cladistic, molecular (28S) and palaeontological analyses supported this interpretation: a first transition from a spiral shell morphotype into the first plesiomorphe straight conica shell (Creseis) wich in turn is ancestral to all the other genus with apomorphic straight shells. It should be emphasised that future studies of currently non available $28 \mathrm{~S}$ sequences for Heliconoides inflata (d'Orbigny, 1835) and Thielea helicoides (Jeffreys, 1877) may impact on these interpretations, require some reserve and need further investigations.

New classification. Spiral shell Euthecosomata: Limacinidae Gray, 1847; Heliconoididae n. fam.; Thieleidae n. fam. Straight shell Euthecosomata: Cavolinioidea Gray, 1850: Creseidae Rampal, 1973; Cavoliniidae Gray, 1850: Cuvierininae Gray, 1847; Cliinae Jeffreys, 1869; Diacriinae n. subfam.; Cavoliniinae Gray, 1850. The genera Styliola Gray, 1850 and Hyalocylis Fol, 1875 are considered genus incertae sedis.

New genera are proposed or reinstated: Telodiacria n. gen., Hyalaea Bosc, 1802 and Boasia 
Dall, 1889.

Most of the species have their taxonomic rank confirmed. The fossil Altaspiratella Korobkov, 1966 was excluded from the Limacinidae while the fossil Vaginella Daudin, 1800 was integrated with the Cuvierininae. Two diversifying events of interest should be highlighted: the late appearance of Hyalocylis (Upper Miocene) despite its lineage starting earlier (Lower Oligocene) and the neoteny process illustrated by Styliola. The integrative approach to the estimation of divergence times, which explained the incongruences concerning Hyalocylis is a powerful tool and could help elucidate other issues, such as the late emergence of archaic phenotypical species Thielea helicoides (Jeffreys, 1877) and Clio polita (Pelseneer, 1888).

\section{ACKNOWLEDGMENTS}

I wish to thank Emmanuel Corse for the molecular analyses and his participation to their interpretation with André Gilles, Yvan Perez and Nicolas Pech (Evolution Génome Environnement, Aix-Marseille Université, France).I am grateful to Philippe Bouchet and Pierre Lozouet (Museum national d'Histoire naturelle, Paris) for the advice on the zoological terminology. I am grateful to the reviewers for the fundamental comments and criticism. I wish to thank Daniel Papillon for the English translation. I also thank Fabien Francl for processing the iconography. 


\section{REFERENCES}

1. ABILDGAARD P. C. 1791. - Nyere efterretning om det skaldyr fra middelhavet, form Forskal Harbeskrevet under navn of Anomia tridentata. Skrivter Naturhistorie-Selskabet Kiobenhavn1 (2): 171-175.

2. BANDEL K., ALMOGI-LABIN A., HEMLEBEN C. \& DEUSER W.G. 1984. - The conch of Limacina and Peraclis (Pteropoda) and a Model for the Evolution of Planktonic Gastropods.- N. Jb. Geological Paläontology Abh.168 (1): 87-107.

3. BANDEL K. \& HEMLEBEN C. 1995. - Observations on the ontogeny of Thecosomatous

4. Pteropods (holoplanktonic Gastropoda) in the Southern Red Sea and from Bermuda. Marine

5. Biology 124 (2): 225-243.

6. BE A. W. H., Mac CLINTOCK C \& CURRIE D.C. 1972. - Helical shell structure and growth of the pteropod Cuvierina columnella (Rang) (Mollusca, Gastropoda). Biomineralisation Research Reports 4: 47-79.

7. BE A.W.H. \& GILMER R. W. 1977. - A zoogeographic and taxonomic review of Euthecosomatous Pteropoda. Oceanic Micropaleontology 1 (6):733-808.

8. BLAINVILLE M. H. DE 1821. - Hyale, Hyalaea (Malacozoa). Dictionnaire de Sciences naturelles, $22: 65-83$.

9. BLAINVILLE M. H. DE 1816-1824. - Dictionnaire des Sciences naturelles. Paris \& Strasbourg: 1-567.

10. BLEEKER J. \& SPOEL S. VAN DER 1988. - Diacria piccola and Diacria maculata two new Pteropod molusc species from the Atlantic and Pacific oceans. Proceedings of the Biological Society of Washington 101 (1): 60-66.

11. BOAS J. E. V. 1886. - Spolia Atlantica. Bidrag til Pteropodernes. Morfology og Systematik sampt til Kunds Kaben om deres geografiske Udbredelse. Videnskabernes Selskabs Skrifter 6 Raekke, Naturvidenskabeling Mathematik Afdeling 4 (1): 1-231. 
12. BONNEVIE K. 1913. - Pteropoda. Reports on the Scientific Results of the 'Michael Sars' North Atlantic deep Sea Expedion 19103 (1): 1-59.

13. BONTES B. \& SPOEL S. van der 1998. - Variation in the Diacria trispinosa group, new interpretation of colour patterns and description of D. rubecula n. sp. (Pteropoda). Bulletin Zoologisch Museum Universiteit van Amsterdam16: 77-84.

14. BOSC L.A.G. 1802.- Histoire naturelle des coquilles contenant leur description, les moeurs des animaux qui les habitent et leurs usages. Deterville, Paris : 1-330.

15. BOSC L. A. G. 1816 -1817. - Nouveau dictionnaire d'Histoire Naturelle. Deterville, Paris.: 1-592.

16. BOUCHET P. \& ROCROI J. - P. 2005.- Classification and nomenclator of gastropod families. Malacologia 47:1-397.

17. BURRIDGE A. K., GOETZE E., RAES N., HUISMAN J. \& PEIJNENBURG K. 2015. Global geography and evolution of Cuvierina pteropods. BMC Evolutionary Biology 15: $1-16$.

18. BURRIDGE A.K., JANSSEN A. W., KATJA T. C. A. \& PEIJNENBURG K. 2016.Revision of the genus Cuvierina Boas, 1886 based on integrative taxonomic data, including the description of a new species from the Pacific Ocean (Gastropoda, Thecosomata).- ZooKeys 619: 1-12.

19. CAHUZAC B. \& JANSSEN A. W. 2010. - Eocene to Miocene holoplanktonic Mollusca (Gastropoda) of the Aquitaine Basin, southwest France. Scripta geologica 141: 1-193.

20. CANTRAINE F. 1841.- Malacologie Méditerranéenne et littorale. Memoire de l'Académie Royale de Bruxelles 13: 1-173.

21. CHEN C. \& BE A. W. H. 1964. - Seasonal distribution of Euthecosomatous Pteropos in the surface waters of five stations in the western North Atlantic. Bulletin of Marine Science of the Gulf and Caribbean 14 (2): 185-220.

22. CORSE E., RAMPAL J., CUOC C., PECH N., PEREZ Y.\& GILLES A. 2013. Phylogenetic Analysis of Thecosomata Blainville, 1824 (Holoplanktonic Opisthobranchia) Using Morphological and Molecular Data. PLOS ONE 8: e5943: 1-20. 
23. CURRY D., 1965. - The English Paleogene Pteropods. Procceding of the Malacological Society of London 36: 357-371.

24. CURRY D. \& RAMPAL J. 1979. - Shell microstructure in fossil Thecosome Pteropods. Malacologia 18: 23-25.

25. DALL W. H. 1889. - A preliminary catalogue of the shell bearing marine mollusks and brachiopods of the south-eastern Coast of the United States, with Illustrations of many of the species. Bulletin of United States National Museum 37: 3-221.

26. DALL W. H. 1921. - Summary of the marine shell bearing mollusks of the North West Coast of America from San Diego, California of the polar sea, mostly contained In the collection of the United States National Museum with Illustrations of hiterto unfigured species. - Smithsonian Institut U.S. Natural Museum Bulletin 112:1-217.

27. DALL W. H. \& SIMPSON C. T. 1900. - The Mollusca of Porto Rico. Bulletin of U.S.Fish Commission (1): 353-524.

28. DAYRAT B., TILLIER A., LECOINTRE G. \& TILLIER S. 2001. - New clade of Euthyneuran Gastropods (Mollusca) from 28S rRNA Sequences. - Molecular Phylogenetics and Evolution, 19 (2): 225-235.

29. DESHAYES G. P. \& MILNE EDWARD H. 1836. - in Lamarck, J.B. Histoire naturelle des animaux sans vertèbes. J.B. Baillière, Paris $2^{\mathrm{e}}$ ed.7: 1-736.

30. DUPONT L. 1979. - Note on variation in Diacria Gray, 1847, with desriptons of a species new to science, Diacria rampali nov. spec. and a forma new to science, Diacria trispinosa forma atlantica nov. forma. Malacologia 18: 37-52.

31. FOL H. 1875. - Sur le développement des Ptéropodes. Archives de zoologie exppérimentale générale 4 (1): 1-214.

32. FORBES E. 1844. - Report on the Mollusca and Radiata of the Aegean Sea and on their distribution considered as bearing on geology. Report of the $13^{\text {th }}$ Meeting of the Britisch Assiation for the Advancement of Science 1843: 131-193.

33. FRONTIER S. 1963. - Hétéropodes et Ptéropodes récoltés dans le plancton de NosyBé. Cahiers O.R.S.T.O.M. Série Océanographie 6: 213-227. 
34. FRONTIER S. 1965. - Le problème de Creseis. Cahiers O.R.S.T.O.M. série océanographie

35. $3(2): 11-17$.

36. GASCA R. \& JANSSEN A. W. 2013. - Taxonomic review, molecular data and key to the species of Creseidae from the Atlantic Ocean. Journal of Molluscan Studies: 1-8.

37. GLAÇON G., RAMPAL J., GASPARD D., GUILLAUMIN D. \& SCOTT STAERKERT. 1994. - 15. Thecosomata (Pteropods) and their remains in late quaternary deposits on the Bougainville Guyot and the Central New Hebrids Island Arc. Proceeding of Oceaographical Drill Programme Science Research 134: 319-334.

38. GRAY J. E. 1847. - A list of the genera of recent Mollusca, their synonymia and types. Proceeding of the Zoological Society of London 15: 129-219.

39. GRAY J. E. 1850. - Catalogue of the Mollusca in the Collection of the Britisch Museum. II Pteropoda. E. Newman London: 1-45.

40. HASZPRUNAR G 1985. - The Heterobranchia a new concept of the phylogeny of the higher Gastropoda. Sond. Z.-f. zoological Systematic Evolution forschung 23: 15-37.

41. HEDLEY C. 1917. - A Checklist of the marine fauna of New South Wales. Part. I. Proceeding of the Royal Society New South Wales (1917) 51: 1-120.

42. HODGKINSON K. A., GARVIE C. L. \& BE A.W. H. 1992. - Eocene Euthecosomatous Pteropoda (Gastropoda) of the Gulf and Eastern Coast of North America. Bulletin of American Paleontology 103(341): 1-62.

43. HOFFMAN H. 1939. - Opisthobranchia In: BRONNS H.G. ed. Klassen und Ordnungen des Tierreichs. Akademischer Verlag. Leipzig 3(2): 219-1118.

44. HUBER G. 1993. - On the cerebral nervous system of marine Heterobranchia (Gastropoda). Journal of Molluscan Studies 59: 381-420.

45. HUNT B., STUGNELL J., BEDNARSEK N., LINSE K., NELSON R. J., PAKHOMOV E., SEIBEL B., STEINKE D. \& WÛRZBERG L. 2010. - Poles Apart: "Bipolar Pteropod Species Limacina helicina Is Genetically Distinct between the Arctic and Antarctic Oceans. PLOS ONE 5 (3): e9835/ 1-4. 


\section{INTERNATIONAL COMMISSION ON ZOOLOGICAL NOMENCLATURE 1999. -}

International Code of Zoological Nomenclature. Fourth edition. The International Trust for Zoological Nomenclature, London: 1-306.

47. ISSEL A. 1869. - Malacologia des Mar Rosso. Biblioteca di Malacologia, Pisa: 1-387.

48. JANSSEN A. W. 1990.- Pteropoda (Gastropoda, Euthecosomata) from the Australian Cainozoic Scripta Geologica 91: 1-76.

49. JANSSEN A. W. 1995. - Systematic revision of holoplanktonic Mollusca in the collections of the 'Dipartimento di Scienze della Terra' at Torino, Italy. Museo regionale di scienze naturali, Torino, Monografie 17:1-233.

50. JANSSEN A.W. 2003. - Notes on systematics, morphology and biostratigraphy of fossil holoplanktonic Mollusca, 13. Considerations on a division of Thecosomata, with the emphasis on genus group classification of Limacinidae. Caenozoic Research 2: 163170.

51. JANSSEN A. W. 2004. - Holoplanktonic molluscan assemblages (Gastropoda, Heteropoda, Thecosomata) from the Pliocène of Estepona (Spain, Malaga). Palaeontos 5: 103-131.

52. JANSSEN A. W. 2005. - Development of Cuvierinidae (Mollusca Euthecosomata, Cavolinioidea) during the Caenozoic: a non-cladistic approach with a re-interpretation of recent taxa. Basteria 69: 25-72.

53. JANSSEN A. W. 2006. - Notes on the systematics, morphology and biostratigraphy of fossil holoplkanktonic Mollusca, 16 . Some additional notes and amendements on Cuvierinidae and

54. on Classification of Thecosomata (Mollusca, Euthecosomata). Basteria 70: 67-70.

55. JANSSEN A.W. 2007. - Holoplanktonic Mollusca (Gastropoda: Pterotracheoidea, Janthinoidea, Thecosomata and Gymnosomata) from the Pliocene of Pangasinan (Luzon, Philippines) Scripta Geologica 135: 29-177.

56. JANSSEN A.W. 2012. - Systematics and biostratigraphy of holoplanktonic Mollusca from the Oligo-Miocene of the Maltese Archipelago. Bolletino del Museo Regionale di Scienze Naturali 28 (2) : 197-601. 
57. JEFFREYS J. G. 1869. - Britisch Conchology. J.v. Voorst, London 5:1-258.

58. JEFFREYS J. G. 1877. - New and peculiar Mollusca of the Eulimidae and other families of Gastropoda, as well as the Pteropoda, procured in the "Valorous" expedition.

Annales Mag. natural History 19 (4): 317-339.

59. JENNINGS R. M., BUCKLIN A., OSSENBRUGGER H. \& HOPCROFT R. R. 2010. Species diversity of planktonic gastropods (Pteropoda and Heteropoda) from six ocean regions based on DNA barcodes analysis. Deep-Sea Research Part II Oceanography 57: $2199-2210$.

60. JOHNSON C. W. 1934. - List of marine Molluscs of the Atlantic coast from Labrador to Texas. Proceeding of the Boston Society Natural History 40 (1): 1-204.

61. KLUSSMANN-KOLB A. \& DINAPOLI A. 2006. - Systematic position of the pelagic Thecosomata and Gymnosomata within Opisthobranchia (Mollusca, Gastropoda), revival of Pteropoda. Journal of zoological Systematic Evolution Research 44 (2): 118129.

62. LALLI C. M. \& WELLS F. E. 1973. - Brood protection in an epipelagic thecosomatous pteropod, Spiratella ('Limacina') Inflata (d'Orbigny). Bulletin of the Marine Science 23 (4): 933-941.

63. LALLI C. M. \& GILMER R.W. 1989. - Pelagic snails. The biology of holoplanktonic gastropod mollusks. Stanford Univ. Press, Stanford: 1-259.

64. LEMCHE H. 1948. - Northern and Arctic techtibranch gastropods. K. danske Videnskabernes Selskabs Skrifter 5:1-136.

65. LINNAEUS C. 1767. - Systema naturae. Editio duodecima reformata Salvii, Holmiae: 533-1327.

66. MAAS A. E., BLANCO-BERCIAL L.\& LAWSON G. 2013. - Reexamination of the species Assignment of Diacavolinia Pteropods using DNA Barcoding. PLOS ONE 8(1): e 53889 .

67. MAY W. L. 1921. - A check-list of the Mollusca of Tasmania. John Vail, Tasmania: 1114.

68. MC GOWAN J. A. 1960. - The systematics, distribution and abondance of Thecosomata 
of the North Pacific. Unpubl. D. Thesis University of California at San Diego: 1-197.

69. MEISENHEIMER J. 1905a. - Pteropoda. Wissenschaftliche Ergebnisse der Deutschen Tiefsee-Expeditionauf dem Dampfer Valdivia 1898-1899 9(1): 1-314.

70. MEISENHEIMER J. 1905 b. - Die Arktischen Pteropoden. Fauna Arctica IV (II) . G. Fischer, Jena: 407-430.

71. MEISENHEIMER J. 1906. - Die Pteropoden der deutschen Süd-Polar Expedition 19011903. Deutschen Süd-Polar Expedition 1901-1903 (Zoology) 1 (2): 92-153.

72. MONTEROSATO M. DI 1878. - Enumerazione e sinonimia delle conchiglie Mediterranee. Giornale di Scienza Naturale ed Economica Palermo 13 (14): 61-115.

73. MONTEROSATO M. DI 1884. - Nomenclature generica e specifica di alcune conchiglie Mediterranee. Palermo Stabilmento Tipografico Virze: 1-152.

74. MORTON J.E. 1946. - The biology of Limacina retroversa. Journal of Marine Biological Association of the United Kingdom 33: 297-312.

75. MORTON J. E. 1958. - Observation on the gymnosomatous pteropod Clione limacina (Phipps). Journal of Marine Biological Association of the United Kingdom 37: 287-297.

76. ODHNER J. 1939. - Opisthobranchiate Mollusca from the western and northern coast of Norway. K. Nor Videnskabernes Selskabs Skriifter 1: 1-93.

77. ORBIGNY A. D' 1836. - VOYAGE DANS L'AMERIQUE MERIDIONALE EXECUTE PENDANT LES anNeEs 1826-1833. Mollusques. BeRtRAnd PaRIS 5 (3): 1-758.

78. ORBIGNY A. D' 1846. - VOYAGE DANS L'AMERIQUE MERIDIONALE EXECUTE PENDANT LES anNeEs 1826-1833. Mollusques. Bertrand Paris AtLAS: PLS. 1-85.

79. PELSENEER P. 1888. - Report on the Pteropoda collected by H.M. S. Challenger during the years 1873-1876. II. The Thecosomata. Reports on the Scientific Results of the Voyage of H. M. S. Challenger during 1873-1876 23(1): 1-132.

80. PFEFFER G. 1880. - Die Pteropoden des Hamburger Museums. Abhandlungen des Naturwissenschaftlichen Vereins in Hamburg 7: 69-99.

81. PHIPPS C. J. 1774. - A voyage towards the North Pole understaken by his Majesty's Command 1773. Bowyer and Nichols London: 1-275.

82. PHIPPS C. J. 1775. - Voyage au pôle boreal fait en 1773. Saillany, Nyon and Pissot 
Paris 1-12: 1-261.

83. PRUVOT-FOL A. 1954. - Mollusques Opisthobranches. Faune de France 58: 1-457.

84. QUOY J. R. C. \& GAIMARD J. P. 1827. - Observations zoologiques faites à bord de L'Astrolabe en mai 1926, dans le détroit de Gibraltar: description des genres Biphore, Carinaire, Hyale, Flèche, Cleodore, Anatife et Briarée. Annales de Sciences Naturelles 10: $225-239$.

85. RAMPAL J. 1964. - Etude de l'opercule de Spiratella (Limacina) inflata (d'Orbigny, 1836). Bulletin de l'Institut Océanographique de Monaco 61 (1285): 1-12.

86. RAMPAL J. 1965 a.- Pteropodes indicateurs hydrologiques. Revue des Travaux de des Pêches maritimes 29 (4): 393-400.

87. RAMPAL J. 1965 b. - Variations morphologiques au cours de la croisance d'Euclio cuspidata (Bosc). Bulletin de l'Institut Océanographique de Monaco 65 (1360): 1-12.

88. RAMPAL J. 1966. - Pêches planctoniques superficielles et profondes en Méditerranée occidentale (Campagne de la «Thalassa» - Janvier 1961- entre les îles Baléares, la Sardaigne et l'Algérois). VI. Ptéropodes. Revue des Travaux de l'Institut des Pêches maritimes 30: 375-383.

89. RAMPAL J. 1967. - Répartition quantative et bathymétrique des Ptéropodes Thécosomes récoltés en Méditerranée occidentale au nord du $40^{\circ}$ parallèle. Remarques morphologiques sur certaines espèces. Revue des Travaux de l'Institut des Pêches maritimes 31 (4): 403-416.

90. RAMPAL J. 1970 a. - Ptéropodes Thécosomes indicateurs d'eau d'influence atlantique en Méditerranée. Journées Etudes planctonologiques. Rapports de la Commission internationale Mer Méditerranée: 45-48.

91. RAMPAL J. 1970 b. - Ptéropodes Thecosomes indicateurs d'eau d'origine orientale en Méditerranée occidentale. Journées Etudes Planctonologiques. Rapports de la Commission Internationale Mer Méditerranée: 49-52.

92. RAMPAL J. 1972. - Structure de la coquille des Ptéropodes au microscope à balayage. Rapports de la Commission internationale Mer Méditerranée, $23^{e}$ Réunion Assemblée plénière, Comité Plancton, Athènes, 1972. 
93. RAMPAL J. 1973. - Phylogénie des Ptéropodes Thécosomes d'après la structure de la coquille et la morphologie du manteau. Compte Rendu de l'Académie des Sciences de Paris, 277, sér. D: 1345-1348.

94. RAMPAL J. 1974. - Structure de la coquille des Ptéropodes au microscope à balayage. Rapports de la Commission internationale mer Méditerranée 22 (9): 133-134.

95. RAMPAL J. 1975. - Les Thécosomes (Mollusques pélagiques). Systématique et Evolution. Ecologie et Biogéographie méditerranéennes. Thèse Doctorat d'Etat, Université de Provence Aix-Marseille II, C. N. R. S. AO 11932: 1-485.

96. RAMPAL J. 1979. - Thécosomes tropicaux dans les sédiments de la mer Tyrrhénienne. Rapports de la Commission internationale Mer Mediterranée 25/26 (8):149-150.

97. RAMPAL J. 1985. - Systématique du genre Creseis (Mollusques, Thécosomes). Rapports de la Commisson internationale Mer Mediterranée 29 (9): 259-253.

98. RAMPAL J. 1996. - Clio oblonga n. sp. (Mollusque Gastéropode, Euthécosome, Cavoliniidae, Clionae) fossile de thanatocoenoses quaternaires de la Méditerranée. Géologie Méditerranéenne 23 (3-4): 175-185.

99. RAMPAL J. 2002. - Biodiversité et biogéographie chez les Cavoliniidae (Mollusca, Gastropoda, Opisthobranchia, Euthecosomata). Régions faunistiques marines. Zoosystema 24(2): 209-258.

100. RAMPAL J. 2011. - Clés de détermination des Thecosomata (Pteropoda) (Mollusca Opisthobranchia Holoplanctoniques) de Méditerranée et de l'Atlantique Eurafricain. Revue des Travaux de l'Institut des Pêches maritimes 37 (3): 369-389.

101. RAMPAL J. 2014. - Cavolinia gibbosa group (Holoplanktonic Opisthobranchia,

Euthecosomata): systematics and problems of synonymy (comment on Arie W. Janssen, 2012). Bolletino Malacologico 50: 1-10.

102. RANG P. C. A. L. 1828. - Notice sur quelques mollusques nouveaux appartenant au genre cléodore et établissement et monographie du sous-genre creseis. Annales de Sciences Naturelles 13: 302-319.

103. RANG P. C. A. L. \&. FERUSSAC D. de 1830. - Uber die Pteropoden und andere Mollusken. Notizen aus dem Gebiete der Natur und Heilkunde 26 (16): 260- 
262.

104. RICHTER G. 1976. - Zur Frage der Verwandtschaftsbeziehungen von

Limacinidae und Cavoliniidae (Pteropoda: Thecosomata). Archiv für Mollusken kunde

Frankfort am Main 107 (1/3): 137-144.

105. SAKTIVEL M. 1974. - A new species of Creseis (Gastropoda, Mollusca) from

the Laccadive Sea. Current Science 43 (19): 619-620.

106. SALVINI-PLAWEN L. 1970. - Zur systematischen Stellung von Soleolifera und

Rhodope (Gastropoda, Euthyneura). Zoologgical Journal of Systematic 97: 285-299.

107. SCHIEMENZ P. 1906. - Die Pteropoden der Plankton Expedition. Ergbenisse

der Nord-Atlantic. Plankton Expedition der Humboldtstiftung, Kiel und Leipzig 2 : 1-37.

108. SOULEYET F. L. A. 1852: In RANG P. C. A. L. and SOULEYET F. L. A. -

Histoire naturelle des mollusques ptéropodes. Monographie comprenant la description

de toutes les espèces. Baillière, Paris: 1-86.

109. SPOEL S. VAN DER 1963. - A new forma of the species Clio pyramidata

Linnaeus, 1767 and a new resting stage of Clio pyramidata forma sulcata Pfeffer (1879)

(Gastropoda Pteropoda). Beaufortia, 10 (114): 19-28.

110. SPOEL S. VAN DER 1964. - Notes on some Pteropods from the North Atlantic.

Beaufortia 10 (121):167-176.

111. SPOEL S. VAN DER 1967. - Euthecosomata a group with remarkable

developmental stages (Gastropoda, Pteropoda). J. Noorduijn Gorinchem: 1-375.

112. SPOEL S. VAN DER 1969a. - The shell of Clio pyramidata L., 1767 forma

lanceolata (Lesueur, 1813) and forma convexa (Boas, 1886) (Gastropoda, Pteropoda).

Vidensk. Meddel. fra Dansk Naturhist. Forening 133: 95-114.

113. SPOEL S. VAN DER 1969b. - Two new forma of Cavolinia uncinata (Rang, 1829)

(Pteropoda, Gastropoda). Basteria 16 (121): 185-198.

114. SPOEL S. VAN DER 1970. - Morphometric data on Cavoliniidae, with notes on a new form of Cuvierina columnella (Rang, 1827) (Gastropoda, Pteropoda). Basteria 34 (5-6): 103-150.

115. SPOEL S. VAN DER 1971. - New forms of Diacria quadridentata (de Blainville, 
1921); Cavolinia longirostris (de Blainville, 1821) and Cavolinia uncinata (Rang, 1829)

from the Red Sea and the East Pacific Ocean (Mollusca, Pteropoda). Beaufortia 19

(243): 1-20.

116. SPOEL S. VAN DER 1973. - Variation in Cavolinia longirostris (de Blainville,

1821) from the Pacific Ocean with description of a new forma (Mollusca, Gastropoda).

Bulletin Zoölogisch Museum, Universiteit van Amsterdam 3 (14): 99-101.

117. SPOEL S. VAN DER 1974. - Geographical variation in Cavolinia tridentata

(Mollusca, Pteropoda). Bijdragen tot de dierkunde 44 (1): 99-112.

118. SPOEL S. VAN DER 1987. - Diacavolinia nov. gen. separated from Cavolinia

(Pteropoda, Gastropoda). Bulletin Zoöllogisch Museum, Universiteit van Amsterdam 11:

77-79.

119. SPOEL S. van DER, SCHALK P. H. \& BLEEKER J. 1992. - Clio piatkowskii a

mesopelagic Pteropod new to Science (Gastropoda, Opisthobranchia). Beaufortia 43

(1): 1-6.

120. SPOEL S. van DER, BLEEKER J. \& KOBAYASI H. 1993. - From Cavolinia

longirostris to twenty-four Diacavolinia taxa, with a phylogenetic discussion (Mollusca,

Gastropoda). Bijdragen tot de Dierkunde, 62: 127-166.

121. SQUIRES R. L. 1989. - Pteropods (Mollusca, Gastropoda) from Tertiary

formations of Washington and Oregon. Journal of Paleontology, 63 (4): 443-448.

122. STREBEL H. 1908. - Die Gastropoden. Wissenschaftliche Ergebnissen

Schwed Südpolar Expedition 1901-19036 (1): 1-111.

123. STEUR A. 1911. - Adriatische Pteropoden. Sitzung Berichte der Mathematisch-

Naturwissen- schaftlichen Klasse Akademie der Wissenschften in Wien 130 (I): 1-22.

124. TESCH J. J. 1913. - Pteropoda. In: F.E. Schulze. Das Tierreich

(herausgegeben von), R. Friedländer and S., Berlin 36: 1-154.

125. TESCH J. J. 1946. - The Thecosomatous Pteropods. I. The Atlantic. Dana

Report 5 (28): 1-82.

126. TESCH J. J. 1948. - The Thecosomatous Pteropods. II. The Indo-Pacific. Dana

Report 5 (30): 1-45. 
127. UJIHARA A. 1996. - Pteropods (Mollusca, Gastropoda) from the Pliocene.

Miyazaki group, Miyazaki Prefecture, Japan. Journal of Paleontology 70 (5): 771-788.

128. VAYSSIERE A. 1915. - Mollusques Eupteropodes (Ptéropodes Thécosomes)

provenant des Campagnes des yachts "Hirondelle" et "Princesse Alice" (1885-1913).

Résultats des Campagnes Scientifiques accomplies sur son yacht pre Albert $1^{\text {er }}$ Prince

souverain de Monaco. 47: 3-226.

129. VIVES F. 1966. - Zooplankton neritico de las aguas de Castellan (Mediterraneo occidental). Investigaciones Pesqueras. 30: 49-166.

130. WÄGELE H., KLUSSMANN-KOLB A., VERBEEK E. \& SCHRÖDL M. 2013. -

Flashback and foreshadowing- a review of the taxon Opisthobranchia. Org. Diversity

Evolution DOI 10. 1007/s13127-013-0151-5.

131. WATELET A. \& LEFEVRE T. 1885. - Note sur des Ptéropodes du genre

Spirialis découverts dans le Bassin de Paris.-Société Malacolologique Belgique 15:

100-103.

132. WELLS F.E. 1978. - Subgeneric relationships in the Euthecosomatous Pteropod genus Limacina Bosc, 1817. Journal of Malacological Society Australia 4 (1-2): 1-5. 


\section{FIGURE LEGENDE}

Fig. 1. - Pallial system: anterior mantle fringes and appendages (ventral view, except indication). A (dorsal view) and A', Limacina retroversa (Flemming, 1823); B, Limacina. helicina (Phipps, 1774); C, Limacina trochiformis (d'Orbigny, 1836); D, Styliola subula (Quoy \& Gaimard, 1827); E, Creseis acicula (Rang, 1828); F, Hyalocylis striata (Rang, 1828). b-bl, balancer-basal lobe; e, expansion. Scale: $0.5 \mathrm{~mm}$.

Fig. 2. - Pallial system: anterior and lateral mantle fringes and appendages (ventral view, except indication). A, ( oral view schema) Thielea helicoides (Jeffreys, 1877); B, Hyalaea cuspidata Bosc, 1802; C, Clio pyramidata Linnaeus, 1767 ( folded asymetric fringe); D, Cuvierina columnella (Rang, 1827); E, Diacria trispinosa (de Blainville, 1821); F, Clio polita (Pelseneer,1888); G, Clio pyramidata Linnaeus, 1767; H, Telodiacria quadridentata (de Blainville, 1821) n. comb. ac, calypter-like appendage; aef, aif, antero-ventral, external and internal fringes; aeff, folded antero-externe fringe; b-bl, balancer- basal lobe; eb, bilobed, expansion; la, lateral appendage; vc, vacuolized cells; vl, ventral lobe. Scale: $0.5 \mathrm{~mm}$.

Fig. 3. - Pallial system: anterior mantle fringes and appendages (ventral view). A, Cavolinia gibbosa (d'Orbigny, 1836); B, Cavolinia uncinata (Rang, 1829); C, Diacavolinia longirostris (de Blainville, 1821); D, Cavolinia tridentata (Niebuhr, 1775); E, Cavolinia globulosa (Gray, 1850); F, Cavolinia inflexa (Lesueur, 1813). ac, calypter-like appendage; aef et aif, antero- external and internal fringes; b-bl, balancer-basal lobe; et, trilobed expansion. Scale: $0.5 \mathrm{~mm}$.

Fig. 4. - Pallial system: lateral mantle fringes and appendages (dorsal view, except indication). A, Cavolinia gibbosa (d'Orbigny, 1836); B, Diacavolinia longirostris (de Blainville, 1821); C, Cavolinia tridentata (Niebuhr, 1775) (ventral view); D, Cavolinia uncinata (Rang, 1829); E, Cavolinia globulosa (Gray, 1850). Idf, lif, Ivfl atero-dorsal, lateral interne and latero-ventral fringe; la, lateral appendage. Scale: $0.5 \mathrm{~mm}$

Fig. 5. - Pallial gland (A-I, schemas; dark area: parallelepipedic cells). A, Limacina Bosc, 1817; B, Thielea Strebel, 1908; C, Creseis Rang, 1828; D, Hyalocylis Fol, 1875; E, Styliola Gray, 1850; F, Clio Linnaeus, 1767; G, Diacria Gray 1847; H, Cavolinia Abildgaard, 1791; I, Cuvierina Boas, 1886; J, SEM microphotograph: a, prismatic cells; b, parallelepipedic cells (dark area); c, dumbbell-chaped prismatic cells 
area

Fig. 6. - Aragonitic structure of the shell (transversal section) SEM microphotographs. A - C , Heliconoides inflata (d'orbigny, 1835) without rostrum: A, median point peristome; B, C, apical and ombilical margin of the peristome; D, E, Heliconoides inflata with rostrum: D, rostrum; E, apical margin; F, Limacina retroversa (Flemming, 1823), section on the apex.

Fig. 7. - Radula. SEM microphotographs. A, A', Thielea helicoides (Jeffreys, 1877); B, Cuvierina columnella (Rang, 1827); C, Styliola subula (Quoy and Gaimard, 1827); D, E, E', Hyalocylis striata (Rang, 1828) (singular specimen); E, extremity of 2 teeth; E' jaw.

Fig. 8. - Radula. SEM microphotographs. A, Clio pyramidata Linnaeus, 1767; B, Clio convexa (Boas, 1886); C, Clio recurva (Childern, 1823); D, Hyalaea cuspidata Bosc, 1802; E, Diacria trispinosa (de Blainville, 1821); F, Diacria rampali Dupont, 1979.

Fig. 9. - Radula. SEM microphotographs. A, B, Cavolinia globulosa (Gray, 1850) (A, Indian Ocean; B, Pacific Ocean); C, Cavolinia sp.; D, E, Cavolinia inflexa imitans (Lesueur, 1813); F, Cavolinia tridentata (Niebuhr, 1775).

Fig. 10. - Radula. SEM microphotographs. A, Cavolinia plana Meisenheimer, 1905; B, Cavolinia.gibboides Rampal, 2002; C, Cavolinia flava (d'Orbigny, 1836); D, E, F, Diacavolinia Spoel, 1987.

Fig. 11. - Hyalocylis striata (Rang, 1828) (singular specimen): A, breack adulte without shell; B, young specimen (photograph, G. Neve). 

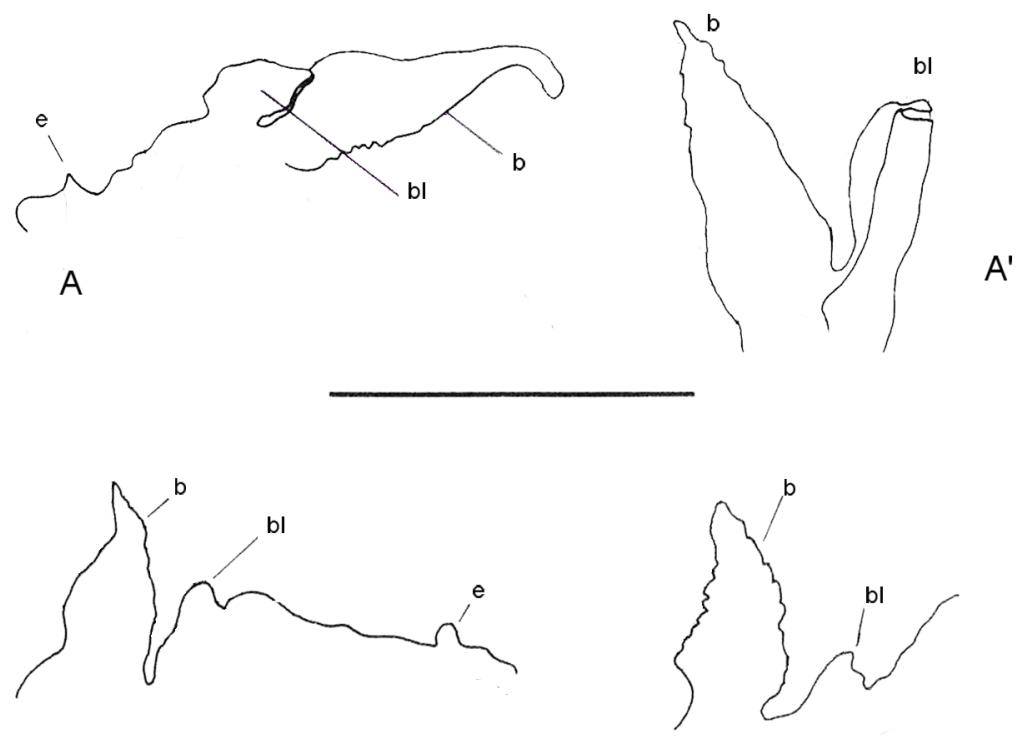

B

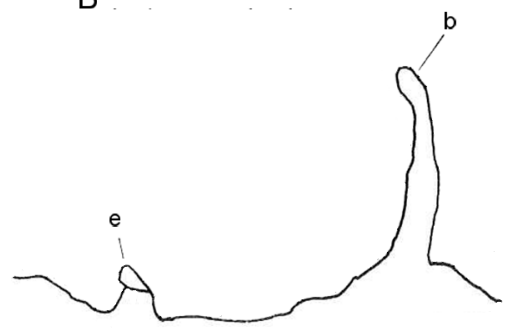

C

D

E

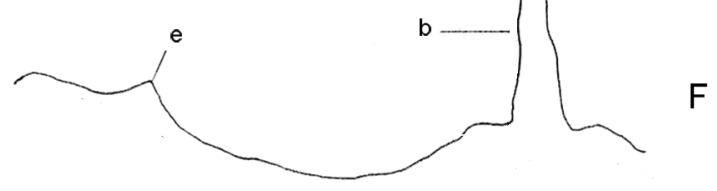




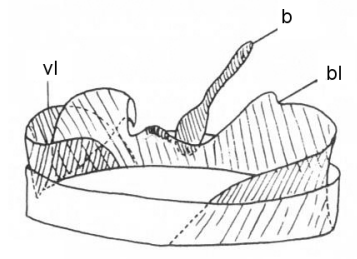

A
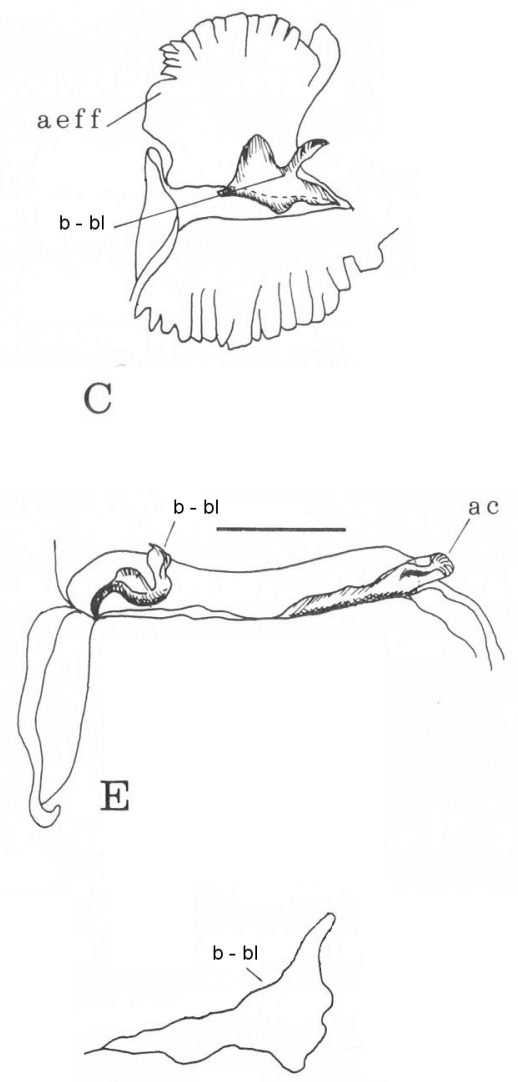

F
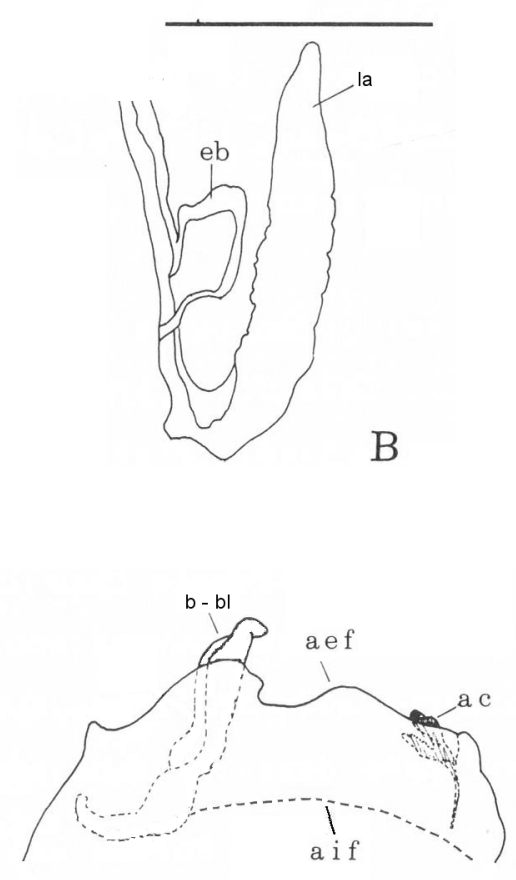

D

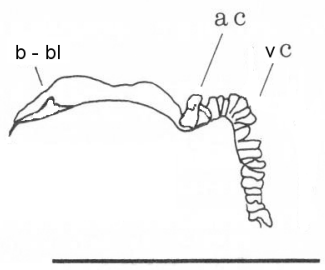

$\mathrm{H}$ 


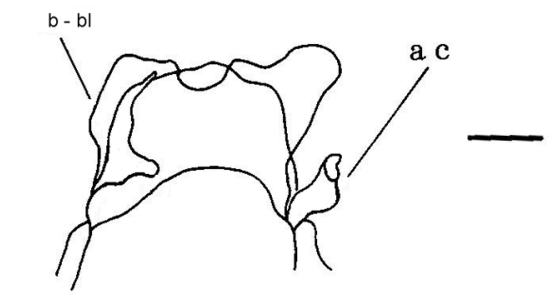

A
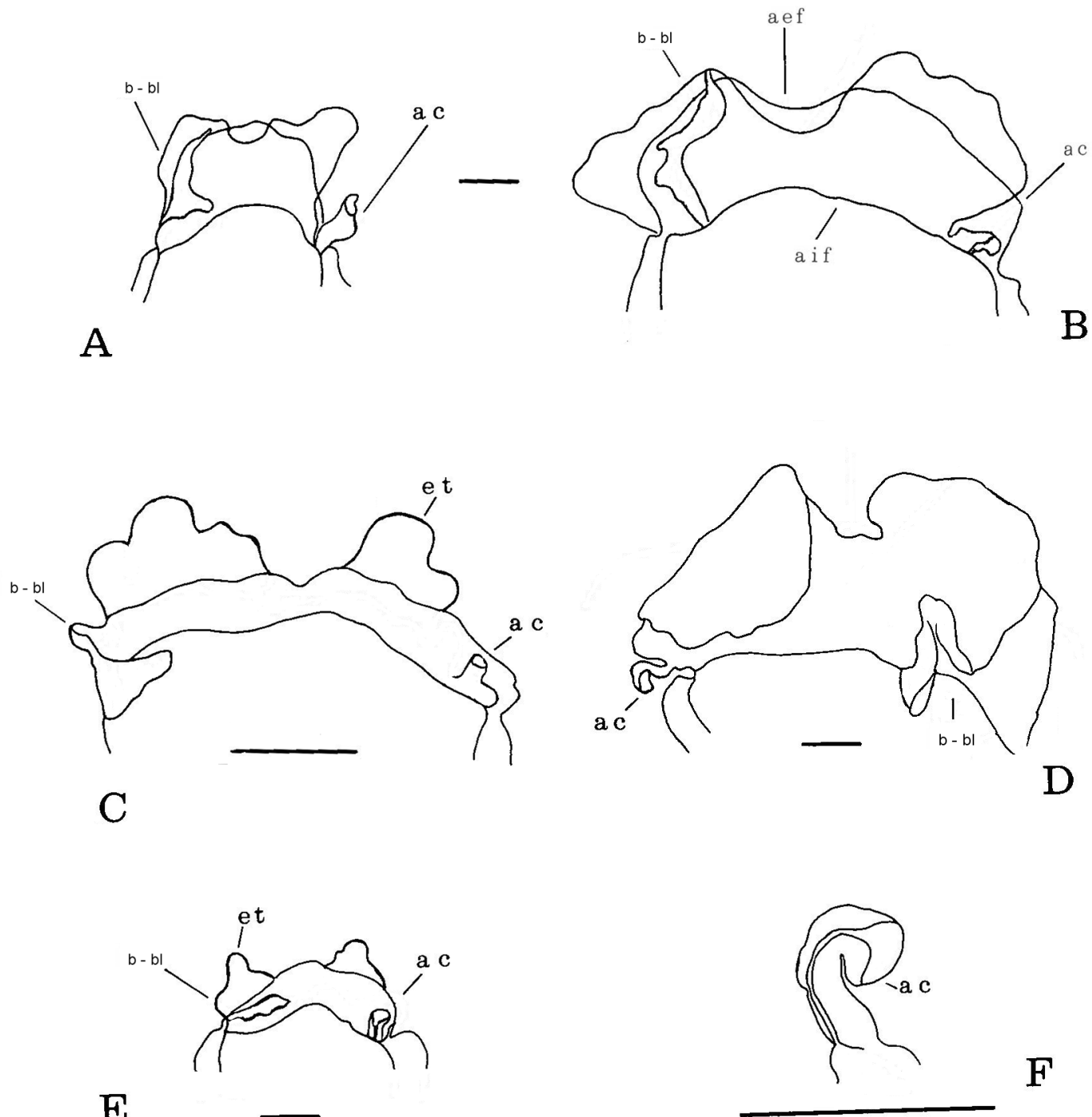

E

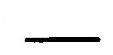




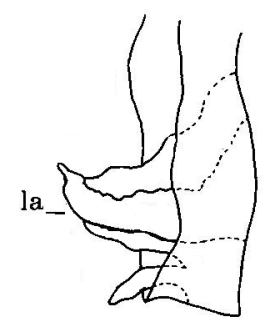

A

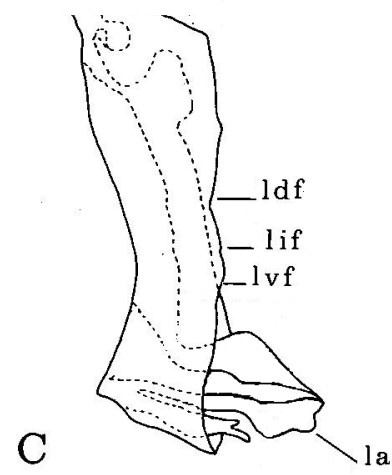

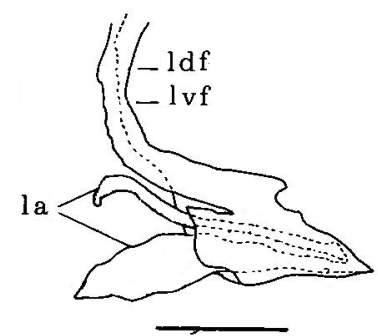

B
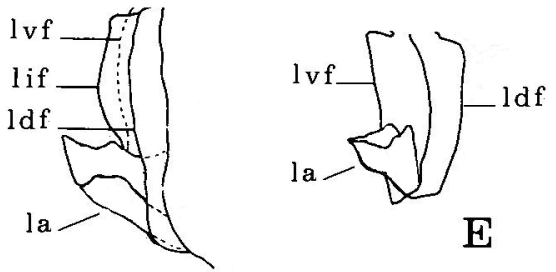

E

D 

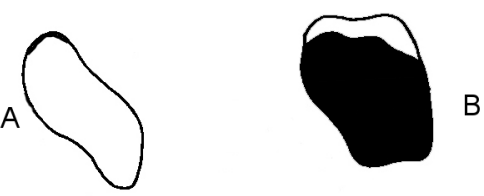

C<smiles>[3H]C1([B])CCCCC1[B]</smiles>

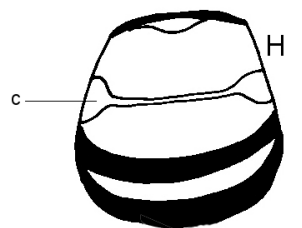

$D$
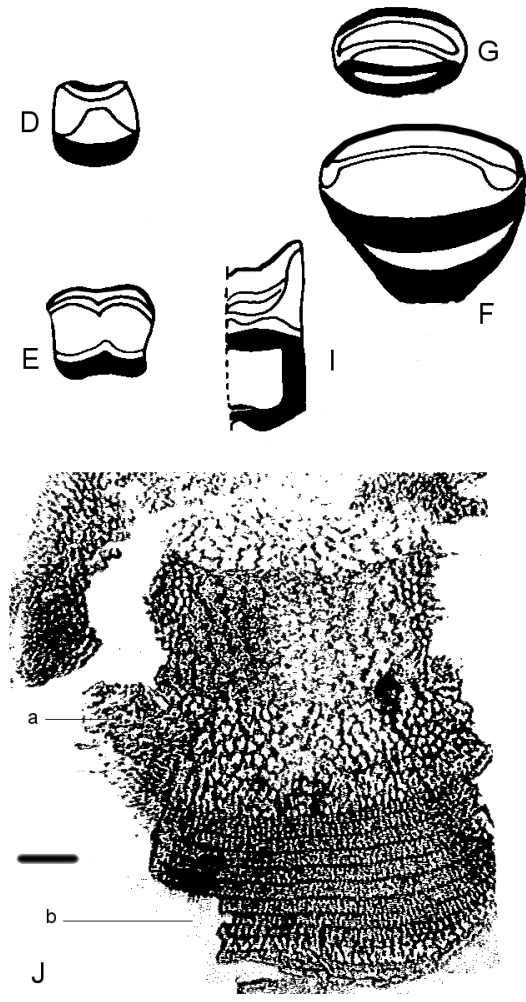

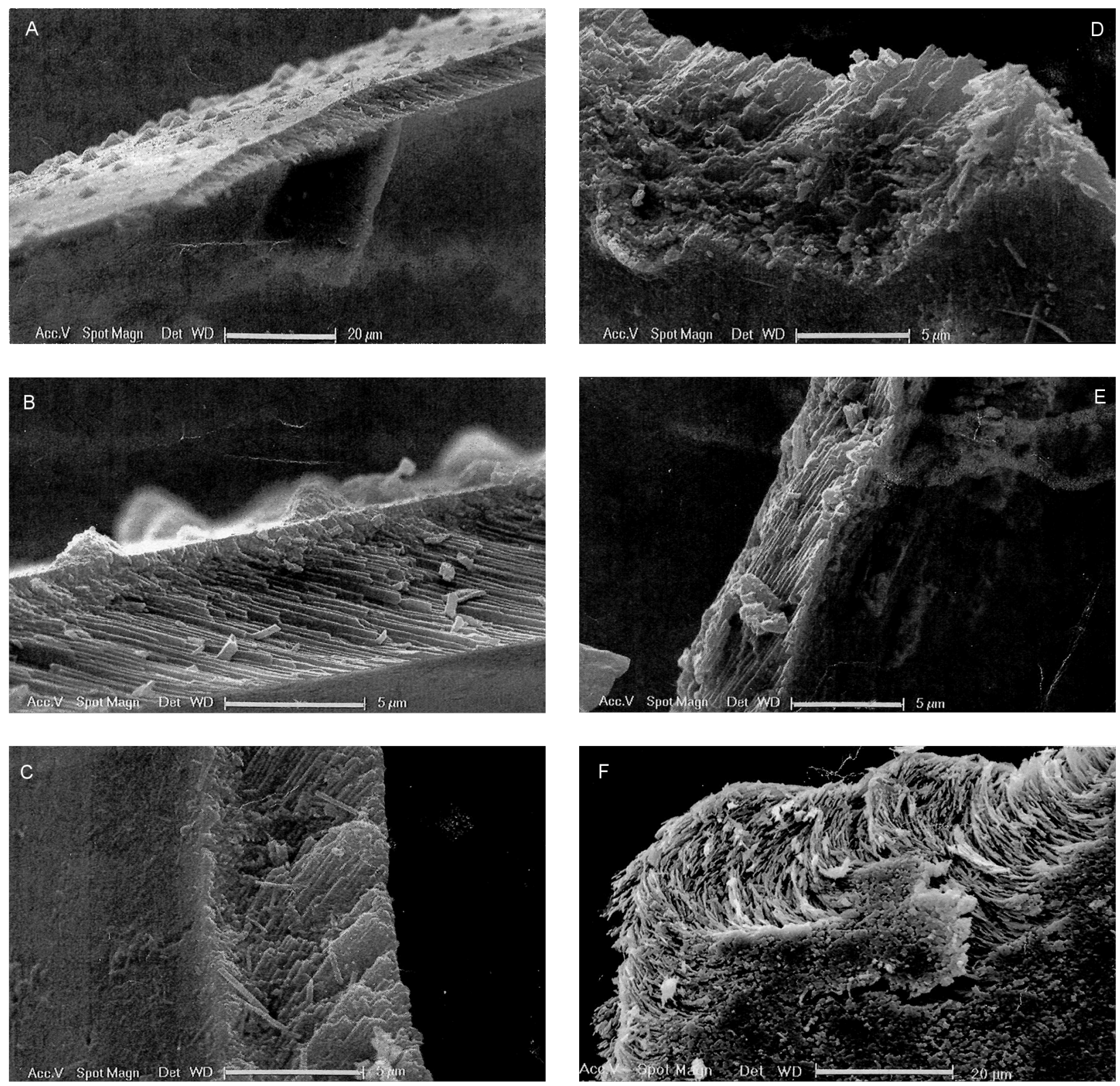

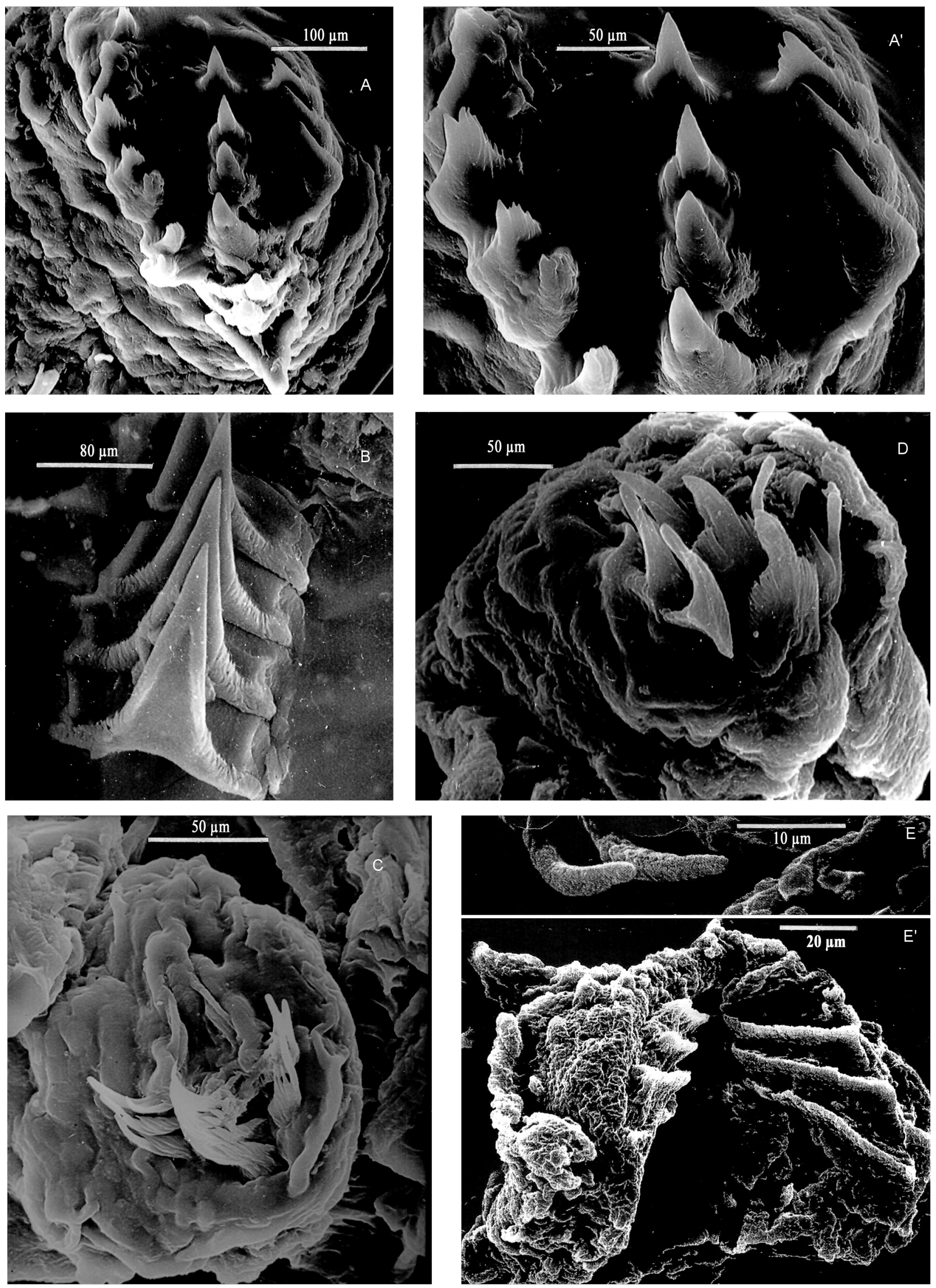

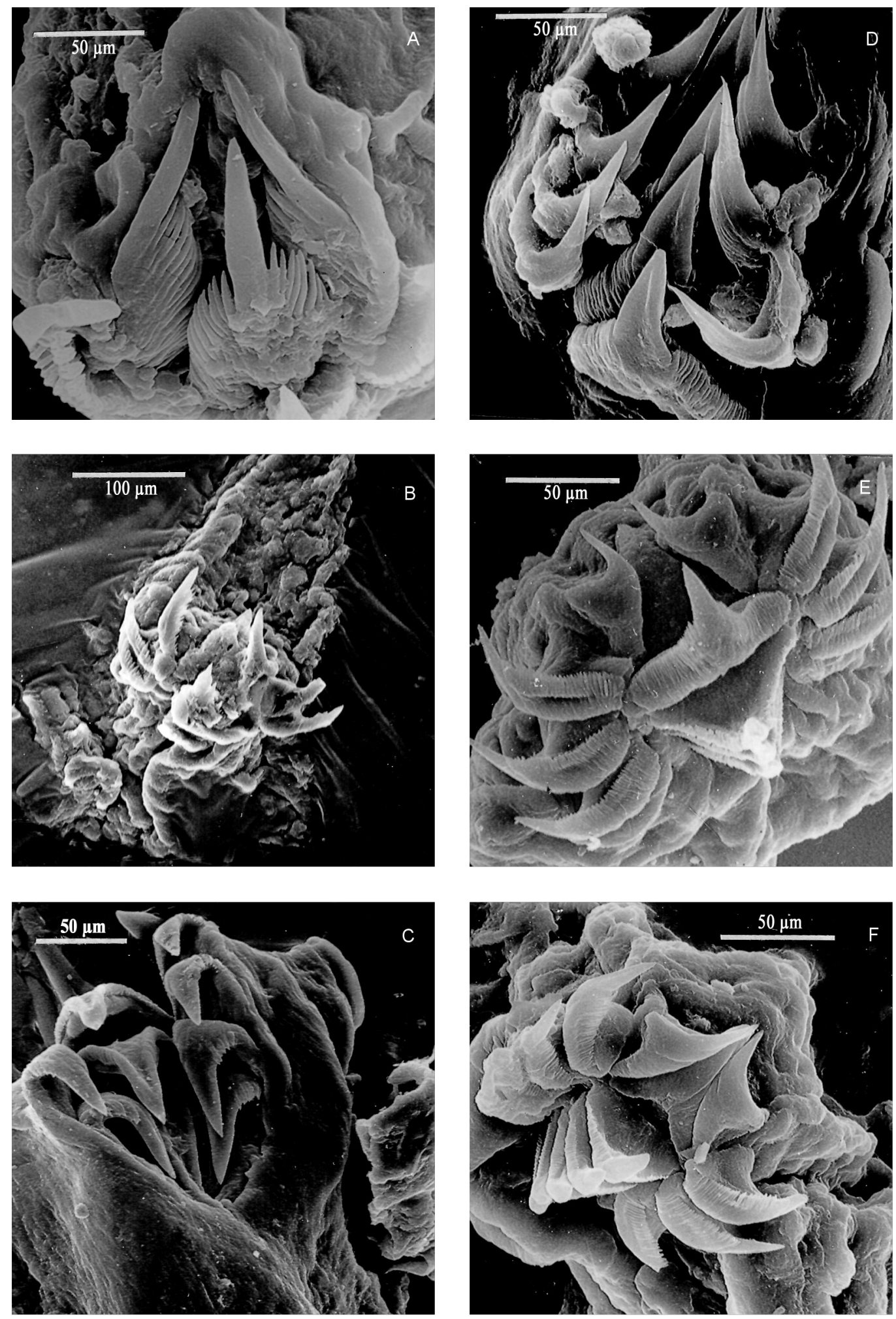

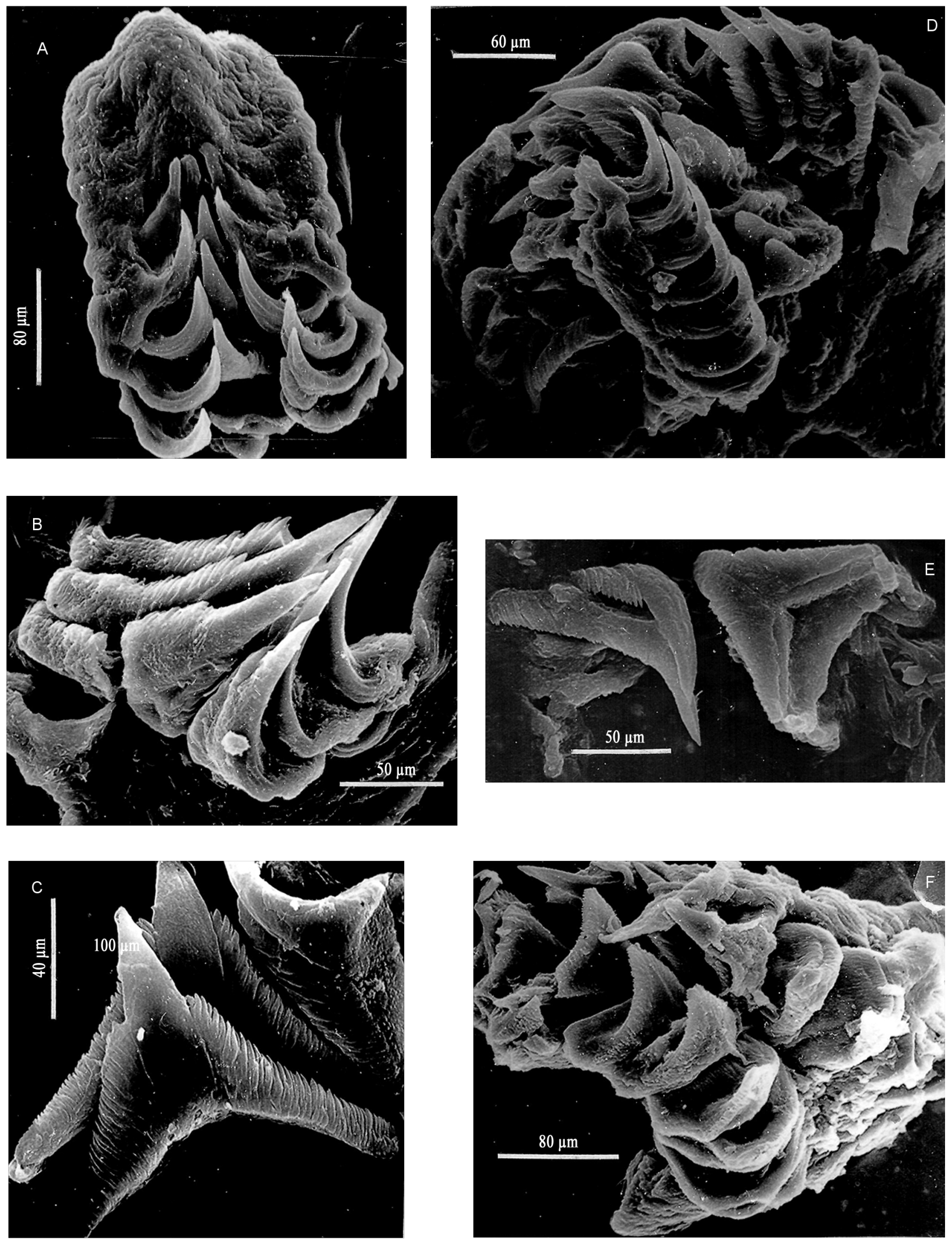

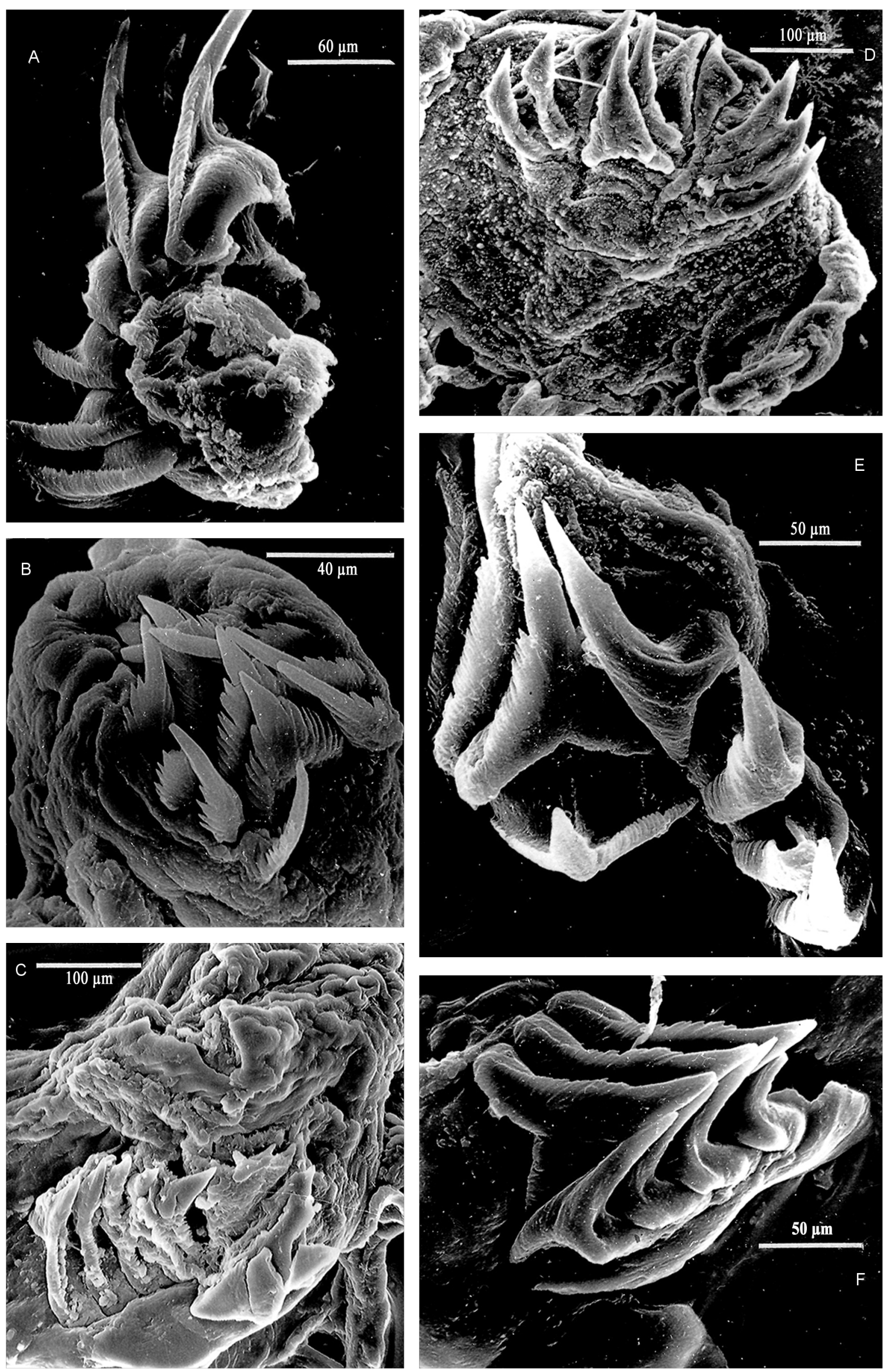

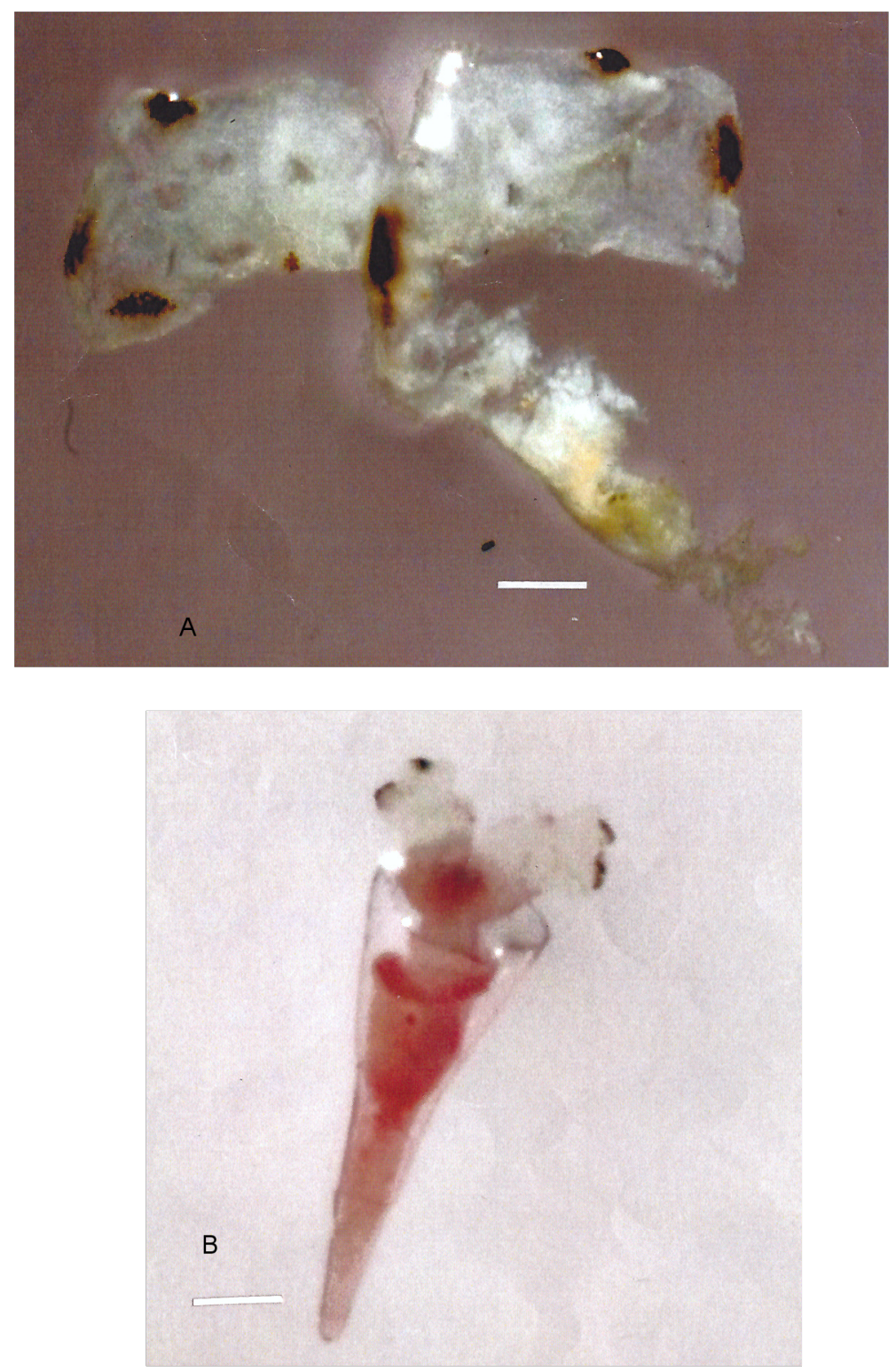